\title{
Groundwater flow dynamics in the complex aquifer system of Gidabo River Basin (Ethiopian Rift): a multi-proxy approach
}

\author{
Abraham Mechal ${ }^{1} \cdot$ Steffen Birk $^{1}$ (D) - Martin Dietzel ${ }^{2}$ - Albrecht Leis ${ }^{3}$. \\ Gerfried Winkler $^{1} \cdot$ Aberra Mogessie $^{1} \cdot$ Seifu Kebede $^{4}$
}

Received: 4 February 2016 / Accepted: 28 October 2016 / Published online: 18 November 2016

(C) The Author(s) 2016. This article is published with open access at Springerlink.com

\begin{abstract}
Hydrochemical and isotope data in conjunction with hydraulic head and spring discharge observations were used to characterize the regional groundwater flow dynamics and the role of the tectonic setting in the Gidabo River Basin, Ethiopian Rift. Both groundwater levels and hydrochemical and isotopic data indicate groundwater flow from the major recharge area in the highland and escarpment into deep rift floor aquifers, suggesting a deep regional flow system can be distinguished from the shallow local aquifers. The $\delta^{18} \mathrm{O}$ and $\delta^{2} \mathrm{H}$ values of deep thermal $\left(\geq 30^{\circ} \mathrm{C}\right)$ groundwater are depleted relative to the shallow ( $<60 \mathrm{~m}$ below ground level) groundwater in the rift floor. Based on the $\delta^{18} \mathrm{O}$ values, the thermal groundwater is found to be recharged in the highland around $2,600 \mathrm{~m}$ a.s.l. and on average mixed with a proportion of $30 \%$ shallow groundwater. While most groundwater samples display diluted solutions, $\delta^{13} \mathrm{C}$ data of dissolved inorganic carbon reveal that locally the thermal groundwater near fault zones is loaded with mantle $\mathrm{CO}_{2}$, which enhances silicate weathering
\end{abstract}

Electronic supplementary material The online version of this article (doi:10.1007/s10040-016-1489-5) contains supplementary material, which is available to authorized users.

Steffen Birk

steffen.birk@uni-graz.at

1 Institute of Earth Sciences, NAWI Graz Geocenter, University of Graz, Heinrichstraße 26, A-8010 Graz, Austria

2 Institute of Applied Geosciences, NAWI Graz Geocenter, Graz University of Technology, Rechbauerstrasse 12, A-8010 Graz, Austria

3 JR-AquaConSol GmbH, Elisabethstrasse 18/II, A-8010 Graz, Austria

4 School of Earth Sciences, Addis Ababa University, P.O. BOX 1176, Addis Ababa, Ethiopia and leads to anomalously high total dissolved solids $(2,000$ $2,320 \mathrm{mg} / \mathrm{l})$ and fluoride concentrations $(6-15 \mathrm{mg} / \mathrm{l})$ exceeding the recommended guideline value. The faults are generally found to act as complex conduit leaky barrier systems favoring vertical mixing processes. Normal faults dipping to the west appear to facilitate movement of groundwater into deeper aquifers and towards the rift floor, whereas those dipping to the east tend to act as leaky barriers perpendicular to the fault but enable preferential flow parallel to the fault plane.

Keywords Hydrochemistry · Stable isotopes · Groundwater flow $\cdot$ Ethiopia

\section{Introduction}

Groundwater is considered as a valuable freshwater resource that can be developed at relatively low cost and provides a buffer in times of drought (Masiyandima and Giordano 2007; Kebede 2013). In the Ethiopian Rift, the development of groundwater resources still appears to be focused on shallow hand dug wells and unprotected springs used for community water supply. Except for in the Kobo and Raya valleys, where the comparative advantages of groundwater irrigation over rain-fed agriculture and surface water irrigation have been demonstrated, the use of groundwater from boreholes for irrigation has been almost non-existent until recently. Nevertheless, recently the use of shallow groundwater for commercial irrigation, as well as industrial use, has increased.

The promise around accelerated use of groundwater for consumptive as well as productive use is hampered by lack of clear knowledge about the groundwater system. The reason for such poor knowledge in the Ethiopian Rift is partly related to the complex hydrogeological setting caused by the strong climate and physiographic difference, variability and lateral 
discontinuity of volcanic rocks, and the disruption of lithologies by faults.

The Ethiopian Rift is part of the East Africa Rift System (EARS), the classic example of a continental rift where the Earth's tectonic forces are currently trying to create new plates (Nubian and Somalian plates). As a consequence of the tectonic activity, typical rift morphology (uplifted highlands and downthrown flat plain rift floor) is well developed causing strong contrast in topography and climate within short distances. Likewise, during the development of the rift, widespread basaltic and rhyolitic volcanic activity has occurred since the Miocene (WoldeGabriel 1990; Chernet et al. 1998). As a result of a series of volcanic activities at different places and times, the stratigraphic sequences are vertically and laterally highly variable. In addition, the volcanic rocks are highly dissected by faults. Two normal fault systems can be distinguished: the roughly NE-SW trending rift boundary faults and a NNE-SSW oriented set of faults affecting the rift floor usually referred to as the Wonji Fault Belt (WFB; e.g. Boccaletti et al. 1998; Mohr 1962).

The level of complexity of the hydrogeological setting is highly variable from region to region in the Ethiopian Rift. Some studies (Ayenew 1998; Ayenew et al. 2009; Kebede et al. 2008, 2010; Bretzler et al. 2011) in different sectors of the Ethiopian Rift showed that they share common characteristics in regard to recharge pattern, groundwater flow direction, hydrochemical evolution and isotopic trends from the highland towards the rift floor. However, the rate of recharge, flow and mineralization, depth of circulation, spatial heterogeneity and interconnectivity of aquifers are different in the distinct sectors of the Ethiopian Rift and show their own peculiar characteristics. For instance, one of the serious problems related to groundwater use in the Ethiopian Rift is poor water quality associated with high salinity and fluoride level (Chernet 1982; Darling 1996; Gizaw 1996; Chernet et al. 2001; Reimann et al. 2003; Tekle-Haimanot et al. 2006). The salinity and fluoride levels of the groundwater vary significantly from place to place, ranging from fluoride-free freshwaters to more saline fluoride-rich waters. Likewise, aquifer productivity and water-table depth vary significantly over short distances (Chernet 1982; Ayenew et al. 2008; Furi et al. 2011). A sound understanding of the regional and local hydrogeological setting is therefore required for an adequate development of groundwater resources in the Ethiopian Rift.

To improve the knowledge about the hydrogeological setting and groundwater flow in the southern Main Ethiopian Rift (MER) Gidabo River Basin was selected as a study area representing the south eastern flank of the MER. This area is characterized by wide topography and climate variation ranging from humid in the highland to semi-arid in the rift floor (Mechal et al. 2015), very complex lithological units (laterally discontinuous and intermixed) and intense faulting. As a result, the hydrodynamics is likely controlled by the heterogeneity of the aquifers and geological structures, which complicates the development and effective use of the groundwater resources. Hydrogeological investigations have been focused mainly on the central MER. In contrast, the existing hydrogeological studies in the Gidabo River Basin, have been reconnaissance surveys and limited to groundwater resource assessment (Raunet 1977; Negussei 1990; Yasin 2002; AG consult 2004; Mechal 2007; Mussie 2007; Debisso 2009). Only recently, Mechal et al. (2015) employed a hydrological model to assess the spatial and temporal recharge distribution within Gidabo River Basin. Using a highly simplifying twodimensional (2D) groundwater flow model, Mechal et al. (2016) showed that measured groundwater levels and the knowledge about the general trends of the hydraulic properties within the basin are consistent with the spatial recharge distribution from the hydrological model; yet, very little is known about the detailed hydrogeology of the area.

The primary objective of this research therefore is to understand the groundwater flow dynamics and the functioning of faults in the Gidabo River Basin, including (1) the hydrochemical evolution, (2) the impacts of tectonic setting of the rift, and (3) finally a conceptual hydrogeological model of the functioning of the Gidabo River Basin. For this purpose, a multi proxy approach using hydrochemical and isotopic tracers in conjunction with hydraulic head and spring discharge observations is applied. This includes the interpretation of hydrochemical and isotope data $\left(\delta^{2} \mathrm{H}, \delta^{18} \mathrm{O}\right.$, and $\left.\delta^{13} \mathrm{C}\right)$ to characterize the chemical evolution of groundwater and the mixing of different flow components (e.g. Clark and Fritz 1997; Herczeg et al. 2001). These techniques were previously employed for investigations of the hydrogeology of active rift systems such as the East African Rift, Dead Sea Rift and Rio Grande Rift (Salameh and Rimawi 1984; Kebede et al. 2008; Chowdhury et al. 2008; Bretzler et al. 2011). In such tectonic settings, variable lithology due to different episodes of volcanic eruptions, high geothermal gradients and emergence in the rift of mantle gases (e.g. $\mathrm{CO}_{2}$ ) escaping through fault zones are very common and may result in a wide range of groundwater compositions. On one hand, major ion chemistry can be used to decipher the major processes controlling the groundwater composition (Darling 1996; Gizaw 1996; Rango et al. $2009)$; however, on the other hand, stable isotopes $\left(\delta^{2} \mathrm{H}, \delta^{18} \mathrm{O}\right)$ have mostly conservative properties and depend strongly on atmospheric conditions during recharge (Gat 1971). Consequently, they provide information about the recharge processes, groundwater flow paths and mixing processes (Fontes 1980; Rose et al. 1996; Mazor 2004).

The combined interpretation of groundwater chemistry and environmental isotopes (e.g. Bethke and Johnson 2008; Leray et al. 2012) thus helps to constrain groundwater flow paths across fault zones and is also helpful to identify different groundwater flow systems. Yet particularly in complex hydrogeological settings where groundwater flow is largely 
controlled by geological structures, the results from hydrogeochemical and isotopic approaches might be ambiguous; therefore, it is desirable to combine hydraulic head observations with environmental tracers (Bense et al. 2013). The hydraulic head distribution can be used to understand the directions of groundwater flow at the fault zone (e.g. Haneberg 1995; Bense et al. 2003, 2008; Bense and Person 2006; Anderson and Bakker 2008) and thus provides an indication of the hydrogeological behavior of the fault zones. In this report, therefore, a combined multi-tracer and hydraulic approach is provided for the hydrogeological characterization of a complex rift aquifer system.

\section{Descriptions of the study area}

\section{Location, physiography and climate}

The study area, Gidabo River Basin, is located in southern Ethiopia in the eastern margin of the MER (Fig. 1). The River Gidabo is the second largest river flowing to Lake Abaya, the largest lake in the Ethiopian Rift, with a $3,302 \mathrm{~km}^{2}$ drainage area, which extends from the center of the rift floor to the mountains of the rift boundary.

The physiographic features of the MER are mainly the results of faulting and volcanism associated with rifting processes. In the southern sector of the MER, where the Gidabo River Basin is located, the collapse of the rift took place fairly regular in a single block. As a result, the typical rift morphology is well developed and the three major physiographic regions, rift floor, escarpment and highland, are clearly visible. The major tectonic scarp connects the rift floor with the uplifted plateau; the plateau rises to elevations of $3,200 \mathrm{~m}$ a.s.l. (Gelala Mountain), whereas the rift floor descends regularly into the Lake Abaya, where it lies at 1,175 m a.s.l. Local increases in the elevation of the rift floor are generally due to volcanic edifices and step faulting. The drainage system of the basin is strongly influenced by the morphology, which in turn is dependent on the geological phenomena. The stream networks commonly show a dendritic drainage pattern and the flow is east-west almost perpendicular to the strike of the escarpment in the upstream; however, in the rift floor the flow deflects to the southwest-northeast direction and displays a sub parallel pattern in the down course sections. There seems to be a strong relationship between the main stream course and geologic structures in the area, especially in the rift floor (Fig. 1).

The climate is highly variable in the Gidabo River Basin and gradually changes from semi-arid in the rift floor to humid in the mountains. In the highlands and escarpment bounding the rift floor, rainfall exceeds $1,600 \mathrm{~mm} /$ year, whilst the lowest elevation of the rift floor receives much less rainfall, often below $800 \mathrm{~mm} /$ year. Precipitation is characterized by a bimodal pattern with a maximum during April and May (small rain season) and a subordinate peak in September and October (heavy rain season). The diurnal variation of temperature in the basin is more visible than its seasonal variation. The average monthly temperature varies from 21 to $25^{\circ} \mathrm{C}$ in the lowlands to less than $11.5-13.5^{\circ} \mathrm{C}$ in the high elevation plateau.

\section{Geological setting}

Being situated in the Ethiopian Rift, the geological cover of the study area (Fig. 1) is the product of a series of volcanic eruptions since the Miocene (WoldeGabriel et al. 1990). In general, the rocks covering the area fall into three major groups: pre-rift volcanic rocks, rift volcanic rocks and post rift sediments. The most important features of these rocks together with the geological structure are compiled from current and previous studies (Mohr 1962; Raunet 1977; WoldeGabriel et al. 1990; Boccaletti et al. 1998; Acocella et al. 2003; AG consult 2004; Korme et al. 2004; Kurz et al. 2007; Mechal 2007; Halcrow 2008; GSE 2012) and summarized, as follows, from the oldest to the youngest.

The pre-rift rocks (Oligocene-middle Miocene) occur mainly in the escarpment and highland and to a lesser extent in the rift floor. This group mainly comprises basalt (PV) and ignimbrite (PNV) and represents the oldest rocks in the area, likely separated from the underlying basement by the residual sandstone to the south of the catchment. Rift volcanic rocks (upper Miocene-Pleistocene) are mainly exposed in the rift floor and dominated by silicic volcanic rocks. A thick succession of stratoid silicics comprising predominantly ignimbrites with subordinate unwelded tuffs, ash flows, rhyolites and trachytes, which is commonly known as the Nazret group (N1$2 n$ ), form parts of the rift floor and also outcrops in the escarpment and highland. In the rift floor, the Nazret group is unconformably overlain by younger volcanic rocks called the Dino formation which comprises coarse unwelded pumiceous pyroclastics (Qdp) and a complex mixture of different pyroclastic materials such as ash, tuff and ignimbrite (Qdi). Rhyolitic lava flows, composed of stratified ash, pumice and rhyolite flows (Qwa) mainly occur to the north of Lake Abaya along the axial zone of the rift but similar prominent volcanoes also have erupted pumice and unwelded tuffs forming volcanic mountains in the highland (Qws). Post-rift sediments (Holocene) such as alluvial (Qa) and lacustrine sediments (Qvs) mainly occur along the lower reaches of the Gidabo River and as patchy deposit along the axial zone of the rift, respectively.

The volcanic sequences and sediments in the area are densely dissected by extensional fault systems resulting from the rifting process (Fig. 1). The major fault types are normal faults having generally similar strike but some dip to the east and others to the west. Chronologically they can be grouped into two distinct fault systems: the older Oligocene-Miocene 
Fig. 1 Location and simplified geological map of the Gidabo River Basin (compiled after Mechal 2007; Halcrow 2008; GSE 2012). Inset map shows the location of the study area within the Ethiopian Rift system

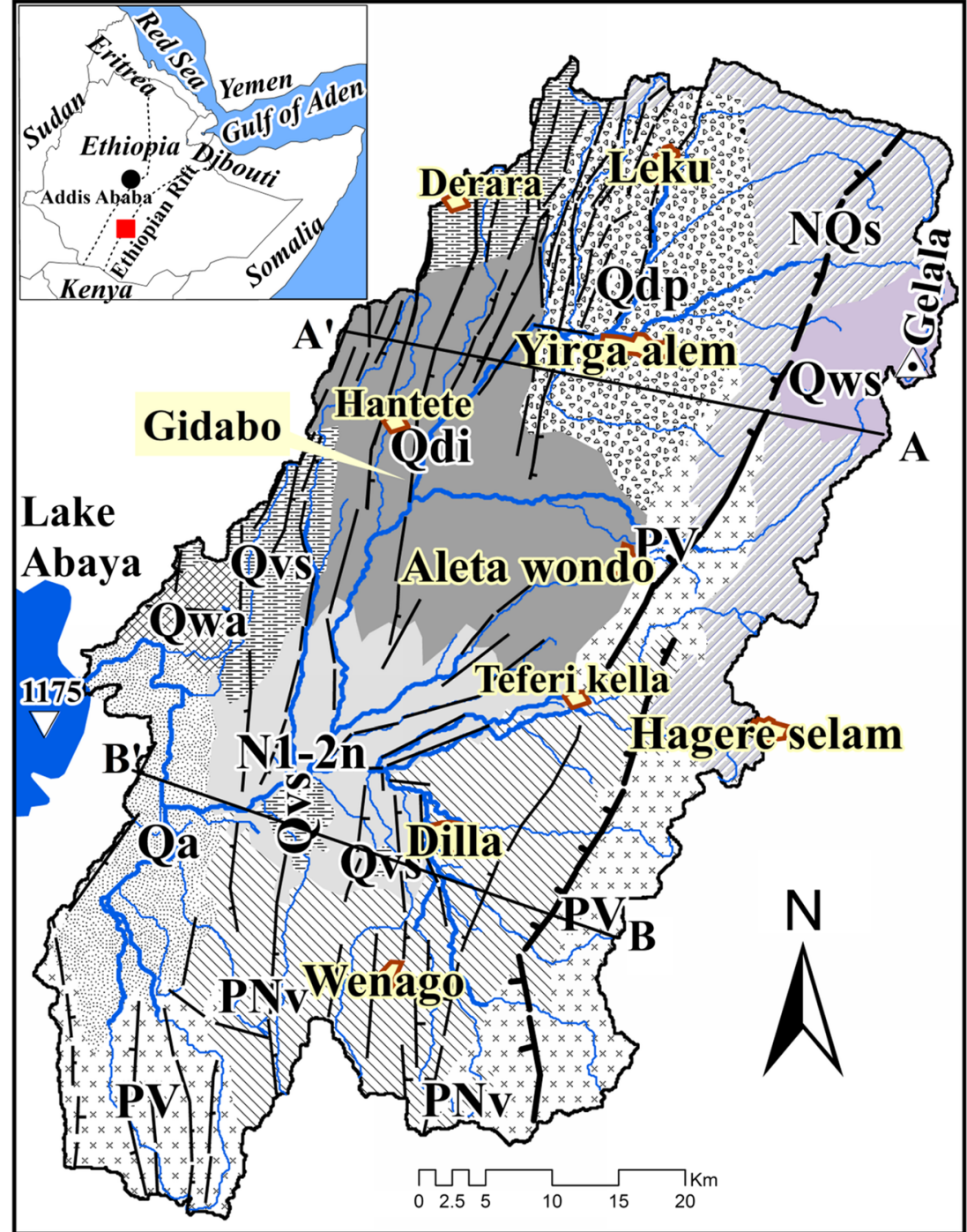

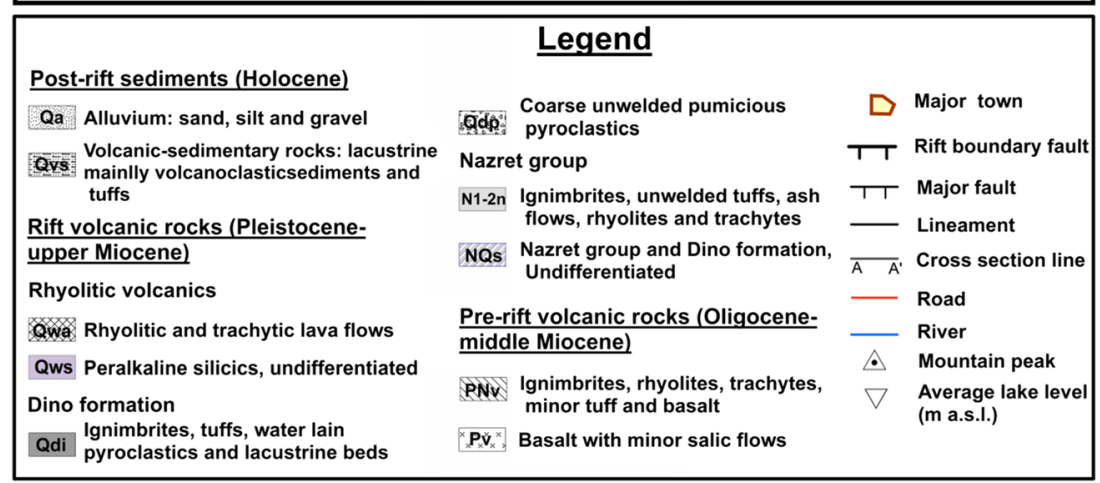

NE-SW trending fault system which characterizes mainly the rift margin, and the younger Quaternary-present NNE-SSW trending set of faults affecting the rift floor, usually referred to as the Wonji Fault Belt (WFB; e.g. Boccaletti et al. 1998; Mohr 1962). The rift margin is well developed and it is defined by a more or less continuous system of boundary faults with a single vertical displacement $(>1,000 \mathrm{~m})$ to the rift floor, whereas the rift floor faults are characterized by short, closely spaced, active faults that exhibit minor vertical throw (5-100 m; e.g. Boccaletti et al. 1998). WFB structures are well developed in the northwestern part of the catchment where right-stepping faults and horst-graben structures are very common (Fig. 1). At places, open fissures with or without vertical displacement are also very common in association with the faults. Main geological units and major stratigraphic sequences with associated fault systems are shown in Fig. 1. 


\section{Hydrogeologic setting}

The hydrogeology of the Gidabo River Basin is complex due to the geometry of the rift, the variability and lateral discontinuity of the volcanic rocks, and the disruption of lithologies by faults. The large topographic differences in the area result in a highly heterogeneous distribution of rainfall and great differences in air temperature causing a highly heterogeneous spatial distribution of groundwater recharge within the catchment. The long-term annual average recharge is estimated to be approximately $236 \mathrm{~mm} /$ year but reveals a remarkable decrease from the highland $(410 \mathrm{~mm} / \mathrm{year})$ towards the rift floor ( $25 \mathrm{~mm} /$ year) reflecting mainly the great differences in climatic conditions (Mechal et al. 2015).

Likewise, the aquifers of the area show vertical as well as lateral heterogeneity. The aquifers are largely the product of volcanic eruptions which occurred in the area at different times and different locations (WoldeGabriel et al. 1990, 2000); and as a result, the rocks have been subjected to different degrees of weathering and fracturing. Between the different eruption time periods, the rocks have been weathered and eroded with subsequent deposition of alluvial materials resulting in multi-layer aquifers with a range of unconfined to semi-confined layers.

The interpretation of pumping tests and well lithologic data (e.g. SWWCE, Awasa, Ethiopia, unpublished report, 2012) obtained from Sidama, Gedeo and Borena Zone Water Resource Development Offices show that interlayered weathered and fractured basalts and ignimbrites are the major aquifers in the highland and escarpment, whereas a mixture of pyroclastic flows (ignimbrite, pumice, tuff and ash) as well as alluvial and lacustrine deposits are the dominant aquifers in the rift floor. Lithologic logs of some selected boreholes in the highland, escarpment and rift floor are presented in Fig. 2. The thickness of the laterally discontinued multi-layer aquifers varies between a few meters to $30 \mathrm{~m}$. In general, unconfined aquifers overlay multiple semi-confined aquifers, and locally in the rift floor artesian aquifers give rise to flowing wells. The transmissivity of the aquifers ranges from 50 to $1,100 \mathrm{~m}^{2} /$ day and generally increases from the highland towards the rift floor. This can be attributed to the increase in the intensity of the fracturing due to tectonic movement towards the rift floor and the occurrence of highly permeable rocks such as pumice and aluvio-lacustrine sediments in the rift floor (Fig. 1). In general, the lithological variations coupled with varied degrees of weathering and fracturing create a high degree of heterogeneity.

\section{Methods and materials}

In two field campaigns (winter 2012 and 2013), structural mapping, water level and spring discharge measurements and water sampling were carried out. Prior to the field investigation, geological structures (lineaments) were delineated by superimposing shaded relief images created from digital elevation models (DEMs) and existing structural maps. The interpretations made were transferred to topographic maps of the same scale later to be checked in the field.

Spring discharge and water level measurements were made in a well-distributed manner in the catchment. Spring discharge measurements were conducted on the developed springs for drinking and domestic water uses. The discharge (1/s) was estimated using a bucket and a stopwatch (volume of the bucket/time to fill the container). Similarly, the groundwater level data were obtained from existing pumping wells for local water supply. When visiting the wells, the location and the elevation were determined using the global positioning system (GPS); the accuracy of which was on the order of 3-5 m. The water level in the well was measured using a dipmeter (Brassington 2007). Before measuring the water level, pumping wells were stopped to allow recovery. An effort was made to search for wells in fault zones and special attention was given during water level measurement for wells placed in the up and down thrown blocks of the faults.

Water samples were taken approximately along NE-SW and $\mathrm{E}-\mathrm{W}$ transects for both isotope and hydrochemical analyses, yielding a total of 57 water samples for the Gidabo River Basin. The samples were collected from rivers (3), springs (14), and wells (40). Prior to sample collection, inactive wells had been pumped for $15 \mathrm{~min}$ to remove the water stored in the well and ensure sampling of primary groundwater; the samples were collected while the pump was running. At springs the water was sampled using a plastic syringe. Separate samples were taken for the analysis of major ions and isotopes of water $\left(\delta^{2} \mathrm{H}\right.$ and $\left.\delta^{18} \mathrm{O}\right)$ and dissolved inorganic carbon $\left(\delta^{13} \mathrm{C}_{\text {DIC }}\right)$. Immediately after sampling, the solutions were filtered through $0.45-\mu \mathrm{m}$ membranes, subsequently stored in polyethylene (HDPE) bottles, and lastly sealed with double caps. Samples for cation analysis were preserved by adding ultra-pure $6 \mathrm{~N} \mathrm{HNO}_{3}$ to the water samples. For carbon isotope analyses $\left(\delta^{13} \mathrm{C}\right)$ of DIC, a 1-ml water sample was injected into a 10 -ml gas-tight vial using a syringe and hollow needle. Prior to going into the field, the vials were preloaded with $0.1 \mathrm{ml}$ of $100 \%$ phosphoric acid, capped and the headspace flushed with He gas in the laboratory (Spötl 2005).

During sampling, field data such as $\mathrm{pH}$, electrical conductivity (EC) and temperature, were recorded. Total alkalinity was measured in situ by titration with $0.1 \mathrm{~N} \mathrm{HCl}$ using methyl orange as the indicator. Major ions samples were analyzed in the laboratory of the Graz University of Technology, Austria. Dissolved cations ( $\mathrm{Na}, \mathrm{K}, \mathrm{Mg}$ and $\mathrm{Ca}$ ) were analyzed using inductively coupled plasma optical emission spectrometry (ICP-OES; Perkin Elmer 4300). Anions (F, Cl, $\mathrm{SO}_{4}$ and $\mathrm{NO}_{3}$ ) were measured by ion chromatography (IC; Dionex 600 ). Isotopic composition of DIC was analyzed using a fully 
Fig. 2 Selected lithologic logs from the highland (SWWCE, Awassa, Ethiopia, unpublished report, 2000), escarpment (SWWCE, Awassa, Ethiopia, unpublished report, 2012) and rift floor (OWWDSE, Addis Ababa, Ethiopia, unpublished report, 2010) showing the multi-layer aquifer nature of the Gidabo River Basin. The screen sections show the aquifers
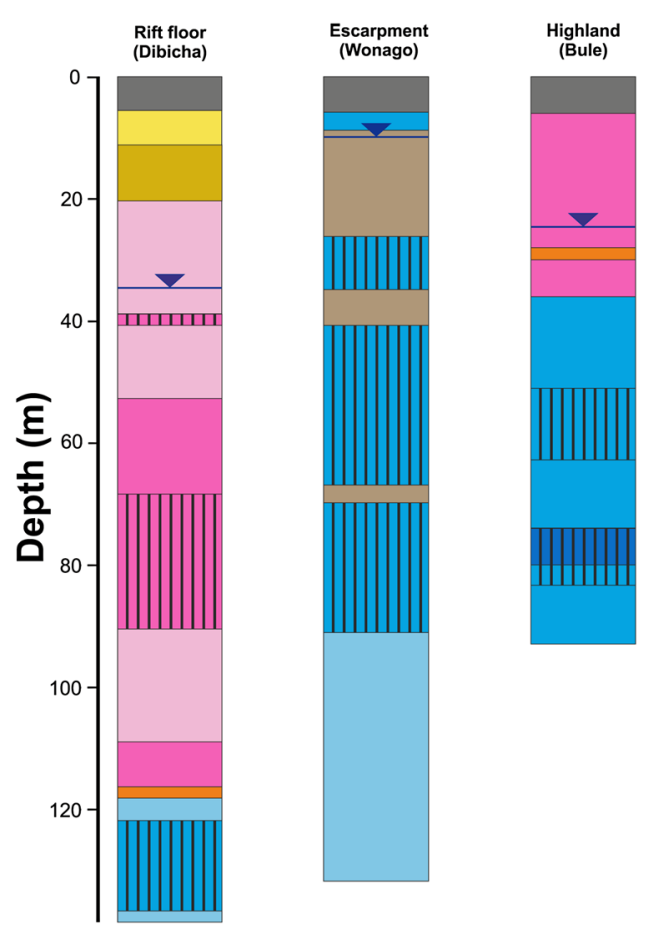

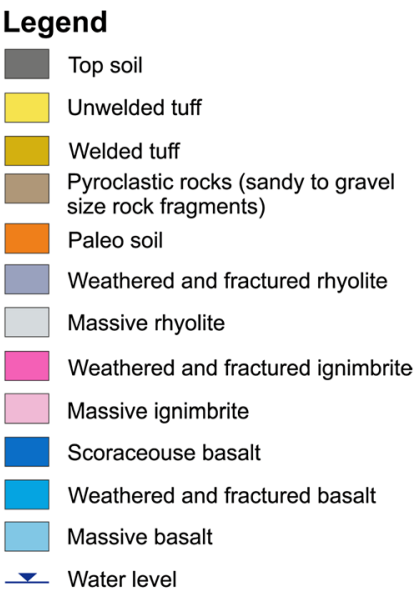

(ESM). The cold springs are very common along the escarpment and are either the result of short breaks in topography (depression springs) or of highly permeable weathered and fractured rocks overlying less permeable rocks (contact springs). Thermal springs are clustered in the rift floor. All thermal springs occur along the faults dipping eastward. In contrast, no groundwater discharge is observed along the westward dipping faults (Fig. 4). The thermal springs are the result of deep artesian aquifers intersected by NNE-SSW trending normal faults. The occurrence of thermal springs only on the eastward-dipping faults suggests that these type of faults not only act as a barrier for flow perpendicular to the fault, but also as a conduit parallel to the fault plane, which further suggests that the westward dipping faults facilitate the deep circulation of the groundwater in the general flow direction towards Lake Abaya.

The field investigation conducted includes discharge measurements of some of the enhanced springs for drinking and domestic water uses (Fig. 4). Almost all springs discharge water throughout the entire year, even during dry seasons; however, their yield highly fluctuates with seasons. The high elevation (highland and escarpment) springs are numerous but have lower discharge $(<0.51 / \mathrm{s})$ than the low elevation (rift floor) springs with a maximum of $150 \mathrm{l} / \mathrm{s}$. In the rift floor, in association with cold springs, thermal springs with a discharge between 6 and $15 \mathrm{l} / \mathrm{s}$ also exist. Although the high elevation springs are very abundant, their cumulative discharge is much less than that of the rift floor springs, which suggests that there are flow paths from the plateau and escarpment (where recharge is high) towards the rift floor (where recharge is low) that provide a large volume of water (mountain-block recharge). 
Fig. 3 Spatial distribution of sampling points in the Gidabo River Basin - the green irregular lines mark the physiographic regions: highland $(2,400-3,207 \mathrm{~m}$ a.s.l.), escarpment $(1,800-$ $2,400 \mathrm{~m}$ a.s.1.) and rift floor (1,170-1,800 m a.s.l.)

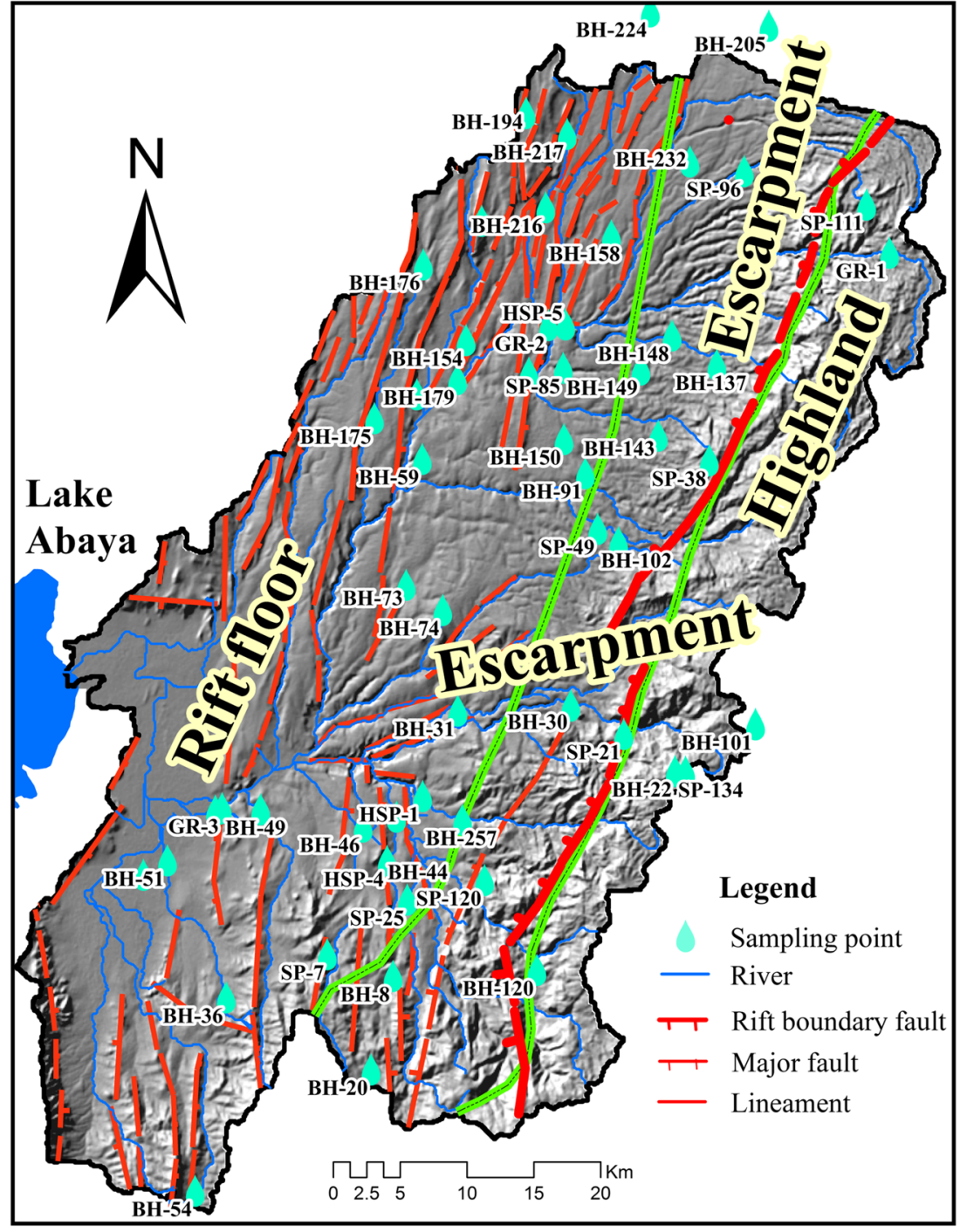

\section{Groundwater level}

Groundwater levels in the study area were found to be variable but the depth to groundwater generally shows an increasing trend from the highland towards the rift floor. The depth to static water level in the highland and escarpment ranges from just below the land surface to approximately $40 \mathrm{~m}$ b.g.l., while in the rift floor it varies from artesian conditions to $244 \mathrm{~m}$ b.g.l. The maximum water level depth was mapped in the northwestern sector of the rift floor.

Figure 4 presents the resulting Gidabo River Basin watertable map. Where limited head observations are available, points of high-yield perennial spring emergence, which are believed to be connected to the static water level, have been used to represent the water level. The interpolated water level demonstrates that steep gradients occur in the escarpment and highland, while shallow gradients occur in the rift floor, which reflects the general topography of the catchment as well as the spatial heterogeneity of the volcanic rocks and spacing and distribution of fractures in the studied region. The steep hydraulic gradients are due to the steep slope and the presence of the relatively low-permeability volcanic rocks in the highland and escarpment, while the low gradients are associated with highly permeable fractured pyroclastic rocks in the flat plains of the rift floor. In general, the equipotential lines indicate the groundwater flows regionally from upland areas in the east towards Lake Abaya, which corresponds to the surfacewater flow direction; thus, the general groundwater flow direction is controlled by the topography. Close to Lake Abaya however, the equipotential lines appear to indicate groundwater flow toward an area south of where the river flows into the lake. Mechal et al. (2016) therefore assumed that the groundwater basin does not coincide with the surface-water divide in this area but extends further southward along the lake. Groundwater flow in this part of the catchment appears to be affected by the faults (see geological structures in Fig. 4). Yet, the low number of wells does not permit a more detailed investigation of the flow pattern in this area. 
Fig. 4 Water-table elevation (m a.s.1.) and spring discharge map

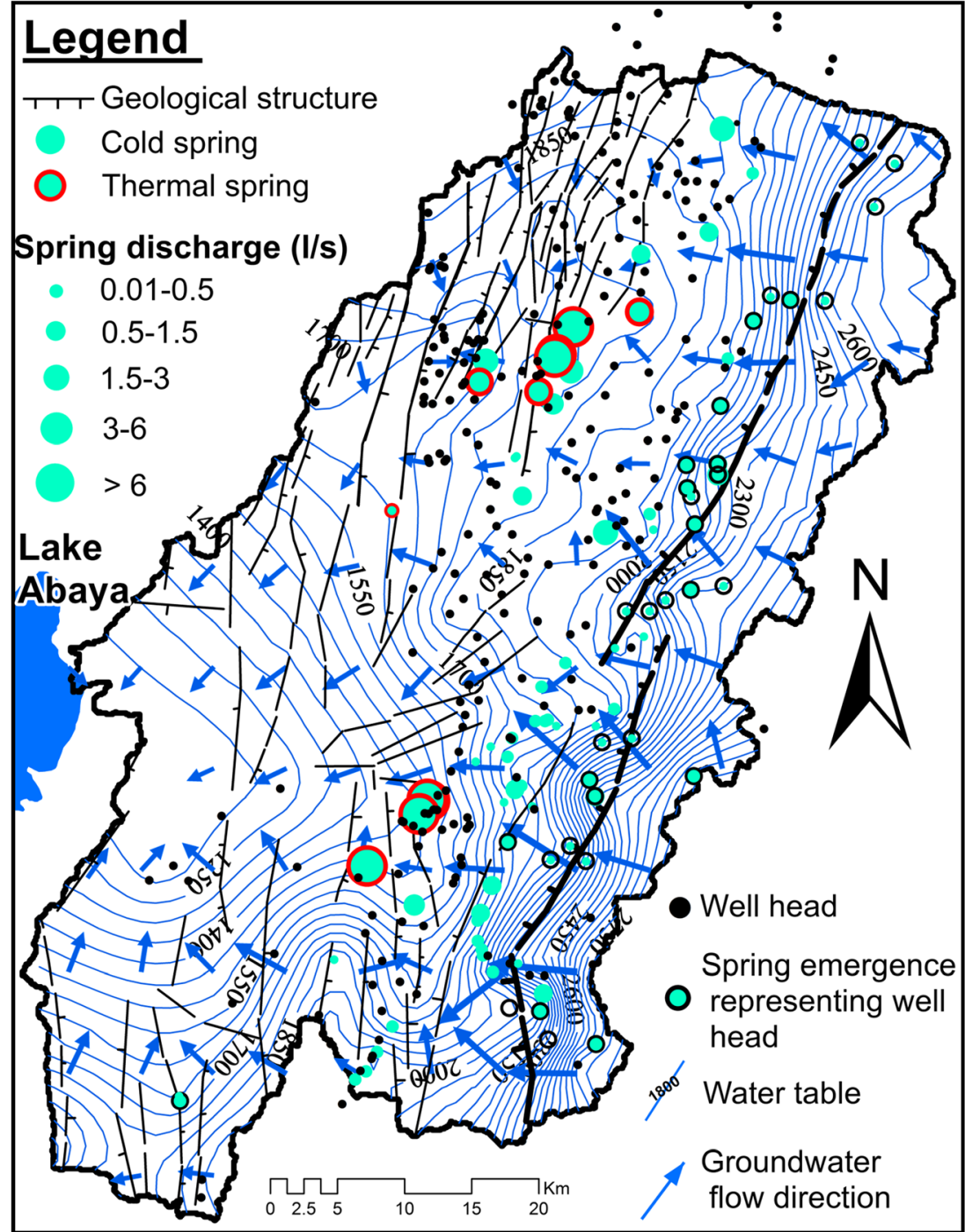

\section{Groundwater chemical composition}

The physico-chemical parameters of the analyzed groundwater samples from the Gidabo River Basin are given in Table 1. Groundwater temperature and the total dissolved solids (TDS) content show extreme variability; however, a clear pattern is observed from the highland towards the rift floor. In the catchment, the temperature of groundwater varies from 14 to $68{ }^{\circ} \mathrm{C}$, while TDS varies from 30 to $2,320 \mathrm{mg} / \mathrm{l}$. Both temperature and TDS show a gradual increase from the highland to the rift floor (Fig. 5a,b) with local anomalies related to thermal waters having high TDS $(2,000-2,320 \mathrm{mg} / \mathrm{l})$. The anomalous chemical composition of these involves high fluoride levels $(6-15 \mathrm{mg} / \mathrm{l})$ exceeding the guideline value of $1.5 \mathrm{mg} / \mathrm{l}$ recommended by WHO (2011). Yet, the majority of groundwater in the Gidabo River Basin displays rather diluted solutions with TDS and fluoride concentrations below 375 and $1.5 \mathrm{mg} / 1$, respectively.
The increase in temperature from the highland towards the rift center is related to an increase in air temperature and geothermal gradient. Groundwater temperature in the deep rift floor aquifers is shifted by more than $10{ }^{\circ} \mathrm{C}$ from the local air temperature, suggesting the connection of these waters to the deep regional groundwater circulation (Fig. 5a). Water-rock interaction along the flow path from the highland towards the rift floor is a likely cause of the observed increase of TDS (Fig. 5b). Mixing with more saline water from deeper horizons or evaporation may also be potential explanations, which will be evaluated by the isotopic composition of the water itself below. Evaporation also results in increasing solute concentrations and can be assessed from chloride and sulfate concentrations. In the absence of chloride and sulfate minerals, these ion concentrations are governed by evaporation rather than by rockwater interaction (e.g. Dogramaci et al. 2015). While chloride and sulfate concentrations are quite low in most waters, the elevated concentrations in the swampy area close 


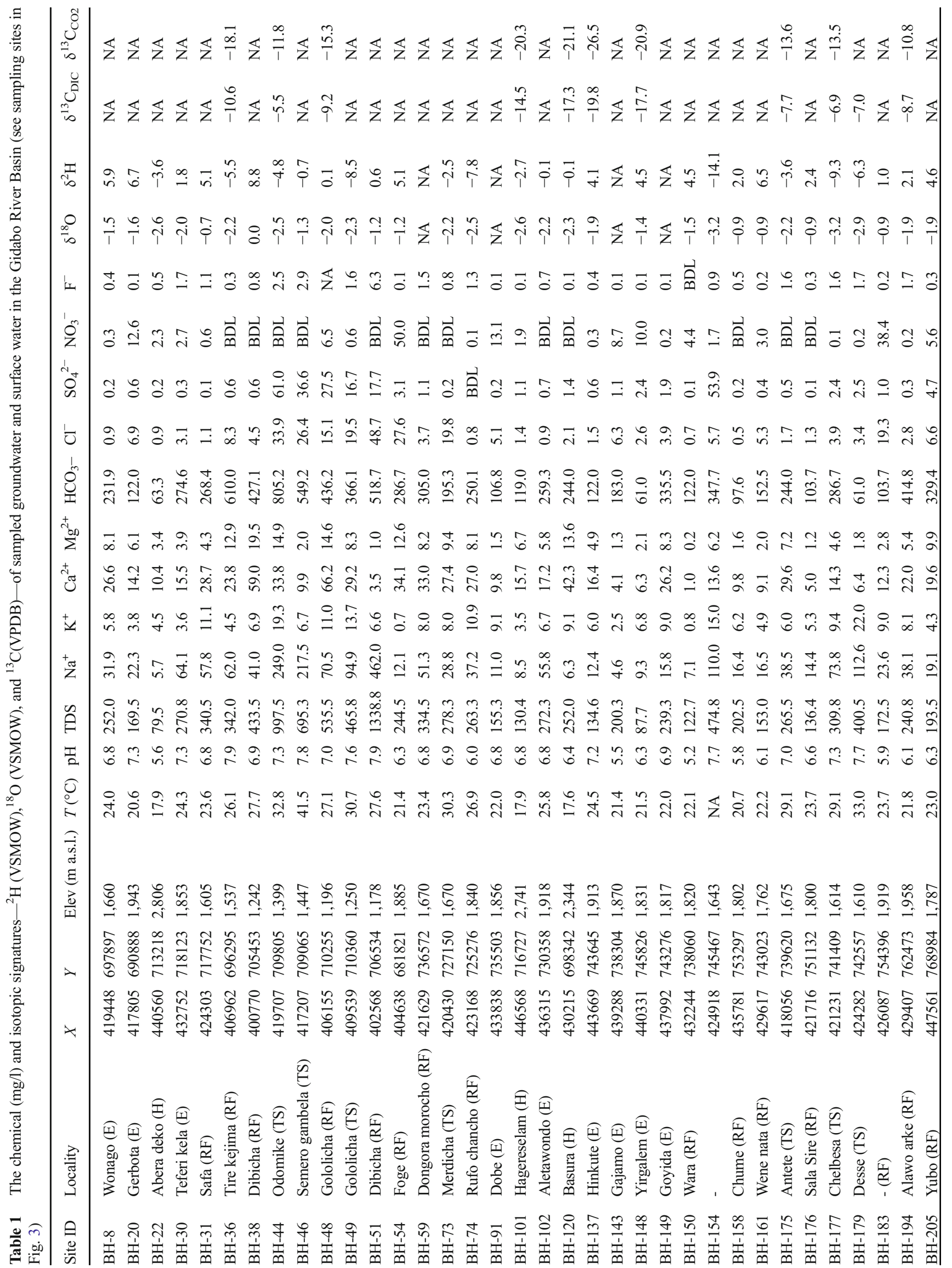




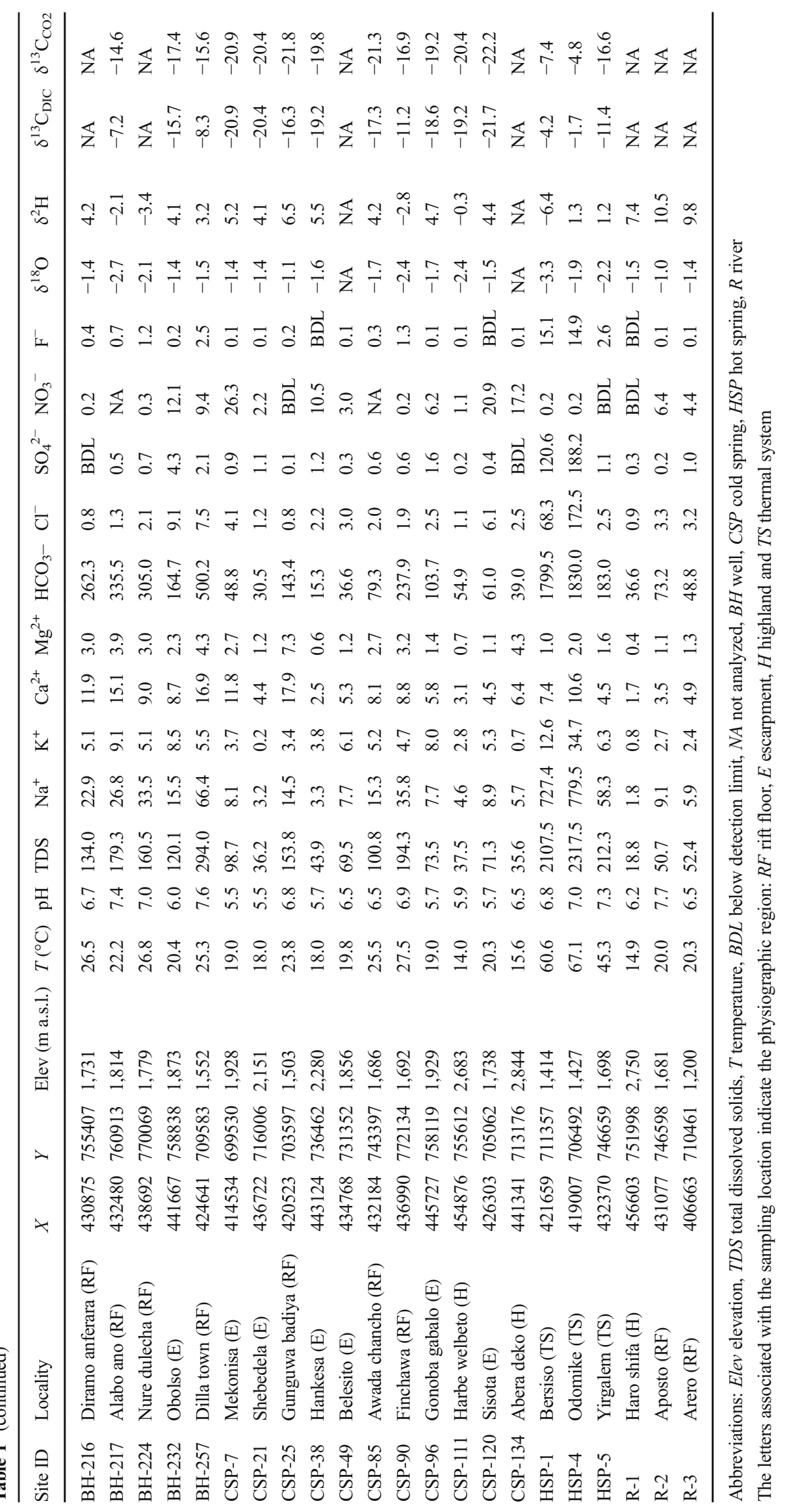


Fig. 5 Spatial variation in groundwater $\mathbf{a}$ temperature and $\mathbf{b}$ TDS from the highland to the rift floor. The relationship of air temperature and elevation in the catchment is represented by: Air temp $\left({ }^{\circ} \mathrm{C}\right)=-0.0053 \mathrm{Elev}(\mathrm{m})+$ 28.05 a

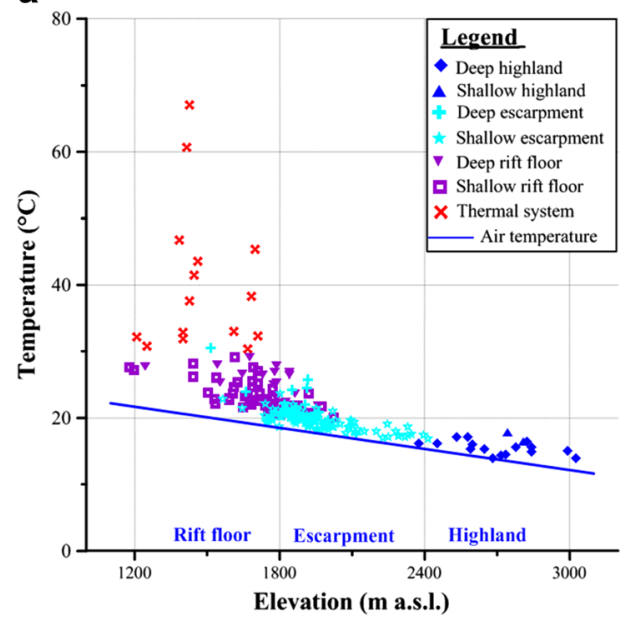

b

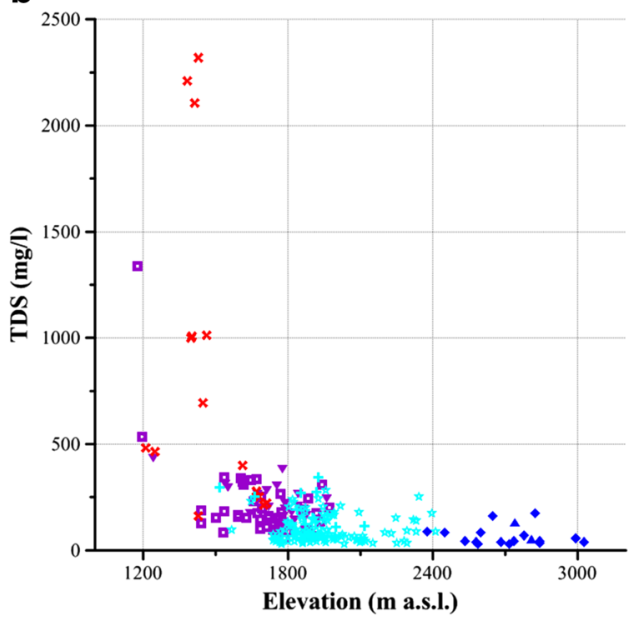

to Lake Abaya indicate local effects of high evaporation (e.g. BH-51; see Fig. 3 and Table 1).

Like temperature and TDS, $\mathrm{pH}$ shows a positive trend towards the rift, from acidic $(\mathrm{pH} 5.2)$ in the uplands to semi-alkaline $(\mathrm{pH} 8)$ in the deep rift floor groundwater. Similarly, the major dissolved ions show a wide variability across the watershed (Fig. 6). The variability in cation concentrations is more noticeable than that in the anion concentrations. $\mathrm{Ca}^{2+}$ is the dominant cation followed by $\mathrm{Mg}^{2+}$ in the highland aquifers but their relative contribution to the total solute content gradually decreases towards the rift floor (Fig. 7). In contrast, $\mathrm{Na}^{+}$displays an increasing trend from the highland to the rift floor. The $\mathrm{K}^{+}$concentration is normally low but shows a positive trend with groundwater temperature; $\mathrm{K}^{+}$is the second dominant cation in the thermal groundwater system. As chloride and sulfate concentrations in the groundwater are mostly low, the dissolved anions are almost exclusively dominated by $\mathrm{HCO}_{3}{ }^{-}$. The measured $\mathrm{HCO}_{3}{ }^{-}$concentrations indicate an increasing trend from the highland towards the rift floor which corresponds to the increase in $\mathrm{Na}^{+}$and $\mathrm{K}^{+}$(Fig. 7). In general, the regional trends in TDS (Fig. 5b) and in the Piper diagram (Fig. 7) indicate a hydrochemical evolution from slightly mineralized $\mathrm{Ca}-\mathrm{Mg}-$

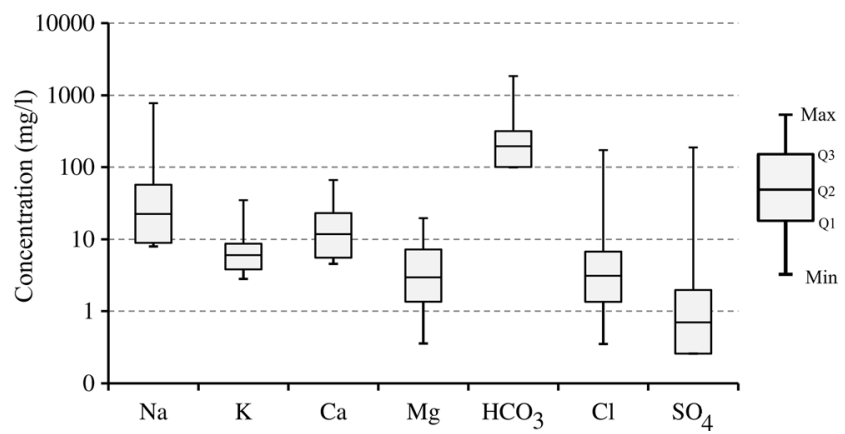

Fig. 6 Variability of chemical composition of the groundwater $(n=57)$. $Q 1, Q 2$ and $Q 3$ represents the first, the second and the third quartile, respectively
$\mathrm{HCO}_{3}$ to moderately mineralized $\mathrm{Ca} / \mathrm{Na}-\mathrm{HCO}_{3}$ and finally to highly mineralized $\mathrm{Na}-\mathrm{HCO}_{3}$ waters along the flow path from the highland to the rift floor.

The major processes controlling the hydrochemical evolution of groundwater in Gidabo River Basin thus appear to be similar to those described elsewhere in the MER (UNDP 1973; Darling 1996; Gizaw 1996; Rango et al. 2009). The dominant hydrochemical process is silicate hydrolysis, which leads to the release of cations like $\mathrm{Ca}^{2+}, \mathrm{Mg}^{2+}, \mathrm{K}^{+}$and $\mathrm{Na}^{+}$and the balancing bicarbonate ion into the groundwater. As the silicate hydrolysis in the study area is controlled by the uptake of gaseous $\mathrm{CO}_{2}$, the $\mathrm{HCO}_{3}{ }^{-}$content is related to concentrations of dissolved cations. This can easily be recognized by the strong correlation of cationic species $\left[\mathrm{Na}^{+}+\mathrm{K}^{+}+\mathrm{Mg}^{2+}+\right.$ $\left.\mathrm{Ca}^{2+}\right]$ and $\left[\mathrm{HCO}_{3}{ }^{-}\right]$, suggesting that the cations are balanced mainly by the bicarbonate anion (Fig. 8). The dominance of $\mathrm{Ca}^{2+}$ and $\mathrm{Mg}^{2+}$ in the highland groundwater (see Fig. 7 and Table 1) is a result of the weathering of olivine, pyroxene and plagioclase, which are major components of basalts (GSE 2012). However, further hydrolysis along the flow path from the highland towards the rift floor through acidic volcanic rocks such as ignimbrite, pumice, tuff, ash, rhyolite and trachyte enriches the water in $\mathrm{Na}^{+}, \mathrm{K}^{+}$and $\mathrm{HCO}_{3}{ }^{-}$, whereas the $\mathrm{Ca}^{2+}$ and $\mathrm{Mg}^{2+}$ enrichment is limited due to lack of the source rocks. The locally high relative $\mathrm{Ca}^{2+}$ and $\mathrm{Mg}^{2+}$ content in the southern part of the rift floor is mostly referred to the down faulted basaltic blocks. Beside silicate hydrolysis, cation exchange may contribute to the increase of the $\mathrm{Na}^{+}$concentration along the flow path from the highland towards the rift floor. In addition to aforementioned geochemical processes, the chemical composition of the groundwater may be altered by mixing processes. The occurrence of thermal springs (e.g. HSP-4) and wells with high TDS values in the vicinity of cold springs (e.g. CSP-25) and shallow wells indicates the existence at least of two major groundwater flow systems in the rift floor: a shallow and a deep circulating groundwater flow system. The strong scattering of groundwater temperatures 
Fig. 7 Piper diagram showing the hydrochemical evolution of groundwater samples from the highland to the rift floor

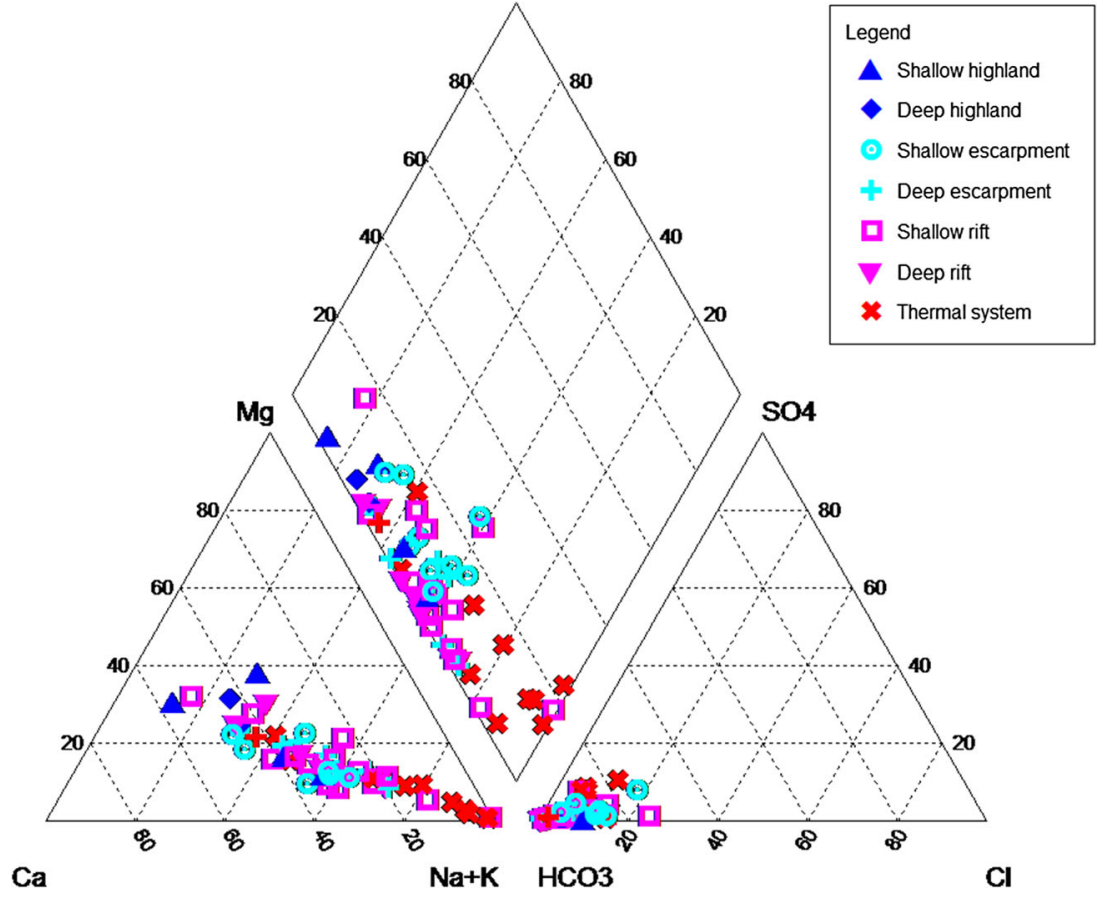

and TDS within the rift floor (Fig. 5a,b) suggests mixing of shallow and deep groundwater, e.g. at fault zones (see section 'Hydraulic data'). Likewise, the wide range of the cation composition particularly in the shallow rift floor, which is evident from Fig. 7, may partly (besides geological heterogeneity) reflect the mixing of different flow components. The description of the hydrochemical evolution given in the preceding suggests that the deeply circulating groundwater is recharged in the upper catchment (highland and escarpment) and chemically altered along its flow path into the rift floor.

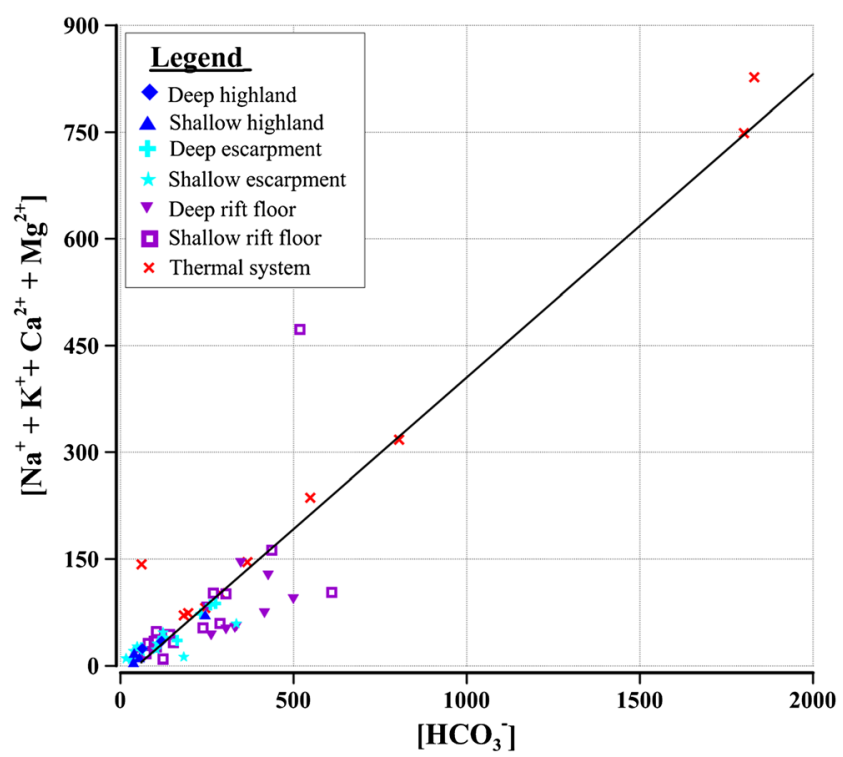

Fig. 8 Relationship between major cation species and $\left[\mathrm{HCO}_{3}{ }^{-}\right]$content $\left(R^{2}=0.88\right)$

\section{Groundwater isotopic composition}

\section{Stable hydrogen $\left(\delta^{2} H\right)$ and oxygen $\left(\delta^{18} O\right)$ isotopes}

$\delta^{2} \mathrm{H}$ and $\delta^{18} \mathrm{O}$ values for local rainfall throughout the study area are not well documented. However, the International Atomic Energy Agency's (IAEA) water resources programme has surveyed the stable isotopic composition of rainfall at Hagreselam station as a part of the Global Network of Isotopes in Precipitation (GNIP) for a relatively short period of time (1999-2001). Hagereselam GNIP station is located in the eastern part of the catchment at about 2,820 $\mathrm{m}$ a.s.l.; the mean precipitation is $1,320 \mathrm{~mm}$. Based on the mean monthly rainfall isotopic data, the Hagereselam Meteoric Water Line (HMWL) $\delta^{2} \mathrm{H}=8.42 \delta^{18} \mathrm{O}+16.82\left(R^{2}=0.96\right)$ is derived. The intercept of HMWL $(16.82 \%$ ) is higher than that of the Global Meteoric Water Line (GMWL; $10 \%$ ) showing higher deuterium $(d)$ excess. This is a very common phenomenon in the Ethiopian highland rainfalls (Sonntag et al. 1979; Joseph et al. 1992; Rozanski et al. 1996; Darling and Gizaw 2002). Kebede (2004) and Levin et al. (2009) confirmed that the $d$ excess is attributed to the mixing of recycled moisture from continental source and direct moisture from the Indian Ocean.

The isotopic composition of $\delta^{18} \mathrm{O}$ and $\delta^{2} \mathrm{H}$ of groundwater samples (Table 1) in the Gidabo River Basin together with HMWL is presented in Fig. 9a. It appears that the groundwater samples plot along or close to the local meteoric line, suggesting that the groundwater originated exclusively from local precipitation without an additional significant input, e.g. from a juvenile magmatic source. Although the isotopic composition of all water samples indicates meteoric origin, the 
Fig. 9 a The $\delta^{18} \mathrm{O}-\delta^{2} \mathrm{H}$ diagram of water samples from the Gidabo River Basin. The HMWL is defined by the relation $\delta^{2} \mathrm{H}=8.42$ $\delta^{18} \mathrm{O}+16.82$, and the GMWL by $\delta^{2} \mathrm{H}=8 \delta^{18} \mathrm{O}+10$ (Craig 1961). b Shallow groundwater $\delta^{18} \mathrm{O}$ vs. elevation. The linear trend shows an isotopic gradient of $-0.15 \%$ per $100 \mathrm{~m}$ of elevation rise $\left(\delta^{18} \mathrm{O}=-0.0015\right.$ elevation $(\mathrm{m})+$ $1.58 ; R^{2}=0.84$ )

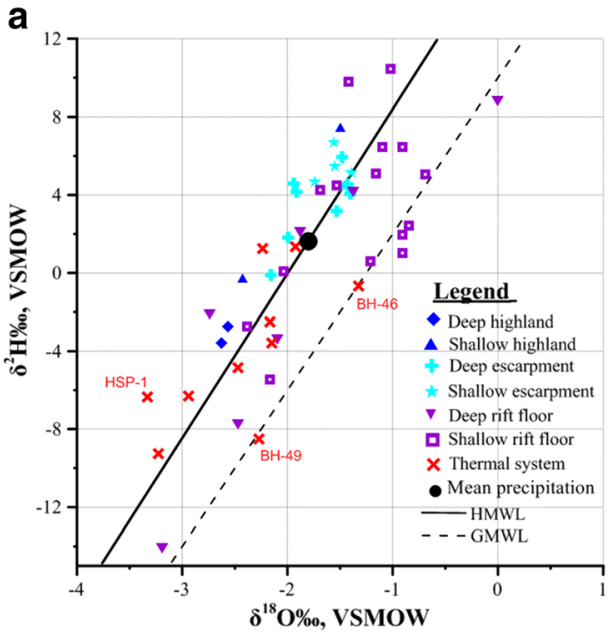

scattering around the meteoric water line suggests that their isotope signature is modified by evaporation and subsurface processes such as isotope exchange with the aquifer matrix. Some of the shallow groundwater samples in the center of the rift floor plot below the HMWL. This is due to evaporative isotope fractionation prior to recharge, which results in discrimination of ${ }^{18} \mathrm{O}$ and ${ }^{2} \mathrm{H}$ versus ${ }^{16} \mathrm{O}$ and ${ }^{1} \mathrm{H}$, respectively, during the evaporation process, and thus heavier isotopes are accumulated in the remaining water (Clark and Fritz 1997). Evaporation is a major process for water loss in the water balance of the basin; it is found to be extremely high in the rift floor (Mechal et al. 2015) and accordingly could considerably modify the isotopic signature of the respective groundwater. Likewise, some of the geothermal boreholes (BH-46 and 49) show a sign of positive ${ }^{18} \mathrm{O}$ shift from the HMWL which might be attributed to high temperature exchange between the groundwater and the siliceous host rock (Craig 1963; Schofield and Jankowski 2004). On the contrary, HSP-1 plots slightly above the HMWL showing a negative ${ }^{18} \mathrm{O}$ shift, which may be related to exchange between the ${ }^{18} \mathrm{O}$ of the waters and that of the $\mathrm{CO}_{2}$ rising through a fault, a wellknown phenomenon in extremely $\mathrm{CO}_{2}$-rich thermal waters (D'Amore and Panichi 1987). In general, evaporation is found to be the major process affecting the isotopic signature of the groundwater in the study area especially in the rift floor, whereas subsurface processes such as water-rock interaction have less influence.

The isotopic signature of the groundwater samples shows a systematic spatial variability across the catchment. As depicted in Fig. 9a, the $\delta^{18} \mathrm{O}$ and $\delta^{2} \mathrm{H}$ values of the groundwater generally show enrichment from the highland towards the rift floor; however, the $\delta^{18} \mathrm{O}$ and $\delta^{2} \mathrm{H}$ of some rift floor samples and particularly of the deep circulating thermal groundwater do not fit into the enrichment trend. The mean values of $\delta^{18} \mathrm{O}$ and $\delta^{2} \mathrm{H}$ in thermal groundwater are depleted from shallow groundwater by 1.1 and $7.3 \%$, respectively, clearly showing a difference in the recharge elevation of the two systems. Assuming a conservative behavior of stable oxygen isotope (Clark and Fritz 1997), the relationship between $\delta^{18} \mathrm{O}$ values and elevation (Dansgaard 1961) is established using shallow groundwater data that represent the average isotopic composition of precipitation in their immediate locality (Fig. 9b). This helps to check the recharge area of the two different groundwater systems. The observed elevation effect $(-0.15 \% / 100 \mathrm{~m})$ is in good agreement with the observation of Kebede and Travi (2011) in the western Ethiopian plateau and the Afar depression $(-0.10 \% / 100 \mathrm{~m})$. Taking into account both $\delta^{18} \mathrm{O}$-elevation relationships, the average recharge elevation for the $\delta^{18} \mathrm{O}$ depleted thermal and deep rift floor groundwater are calculated to be $2,600 \mathrm{~m}$ a.s.l. This elevation belongs to the highland physiographic region, which ranges approximately from 2,400 to $3,200 \mathrm{~m}$ a.s.l. Therefore, the $\delta^{18} \mathrm{O}$ and $\delta^{2} \mathrm{H}$ depleted groundwater in the rift floor is deep circulating groundwater that originated from the highland and parts of the escarpment, while the rift floor aquifers are recharged from local precipitation. In other words, the rift floor aquifers are hydraulically connected to the escarpment and highland aquifers, a conclusion which is also substantiated by the results from the hydrochemical study. Thermal groundwater is highly mineralized $\mathrm{Na}-\mathrm{HCO}_{3}$ type water generated by water-rock interaction along the flow path from the highland to the rift floor, while shallow groundwater is locally circulating $\mathrm{Na} / \mathrm{Ca}-\mathrm{HCO}_{3}$ type water, which compared with the thermal water is characterized by lower temperature, lower $\mathrm{pH}$ and lower TDS.

As the aquifer system of the area is characterized by unconfined aquifers overlying semi-confined aquifers and the existence of intense fracturing (faults; Fig. 1), links between shallow and deep circulating groundwater system are assumed to exist. In order to detect the possible mixing of the two identified groundwater flow systems, $\delta^{18} \mathrm{O}$ versus temperature (Fig. 10) were plotted. In the absence of mixing, the thermal waters would be expected to have $\delta^{18} \mathrm{O}$ signatures clearly different from the colder shallow waters of the rift floor; 


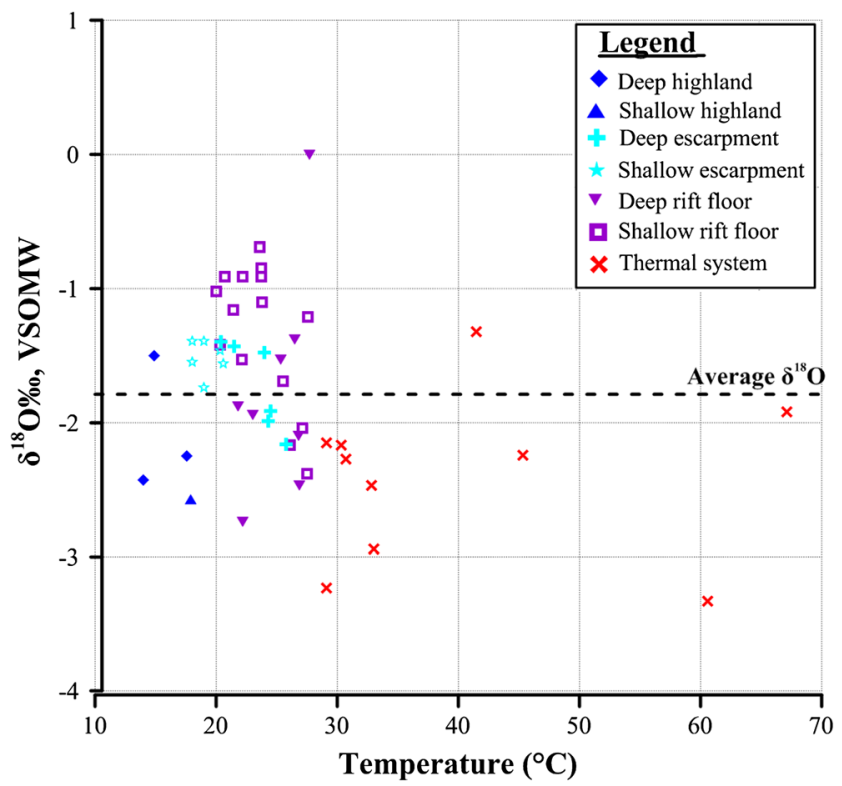

Fig. $10 \delta^{18} \mathrm{O}$ vs temperature of groundwater

however, the $\delta^{18} \mathrm{O}$ versus temperature plot shows that although the $\delta^{18} \mathrm{O}$ values of the thermal groundwater tend to lower values, both thermal water and other rift floor samples scatter around the mean value of the data set. This suggests mixing between the thermal groundwater and the shallow groundwater within the rift floor.

$\delta^{2} \mathrm{H}$ or $\delta^{18} \mathrm{O}$ values can be used to quantify the regionalscale mixing of groundwater of different recharge origin, aquifers and flow systems (Clark and Fritz 1997). To estimate the percentage of the shallow groundwater contribution to the thermal groundwater system a simple two-component system was conceptualized. To simplify the calculation of the mixing proportion, it is assumed that the sampled thermal groundwater is a mixture of two end-members, a deep circulating thermal water component and a non-thermal groundwater located in the rift floor and highland. Samples that were determined to be influenced by processes other than mixing (e.g. BH-46, BH-49, HSP-1 as discussed already) were discarded. The remaining data points are focused on parts of the rift floor close to the edge of the escarpment. The mean values used for the calculation are given in Table 2. Assuming a conservative behavior of $\delta^{18} \mathrm{O}$, mixing of shallow cold groundwater with thermal groundwater in the rift floor is estimated using the binary mixing equation:

Table 2 Mean and standard deviation of the $\delta^{18} \mathrm{O}$ composition of the thermal and shallow highland and rift-floor groundwater systems used for the mixing calculation

\begin{tabular}{ll}
\hline System & $\delta^{18} \mathrm{O}(\% \circ)$ \\
\hline Shallow groundwater in the highland $(n=4)$ & $-2.5 \pm 0.17$ \\
Shallow groundwater in the rift floor $(n=13)$ & $-1.2 \pm 0.45$ \\
Thermal groundwater $(n=7)$ & $-2.1 \pm 0.23$ \\
\hline
\end{tabular}

$\delta^{18} \mathrm{O}_{\mathrm{TS}}=\mathrm{X} \cdot \delta^{18} \mathrm{O}_{\mathrm{RSGW}}+(1-\mathrm{X}) \cdot \delta^{18} \mathrm{O}_{\mathrm{HGW}}$

where $\delta^{18} \mathrm{O}_{\mathrm{TS}}=$ mixed thermal groundwater; $X=$ volume proportion; $\delta^{18} \mathrm{O}_{\mathrm{RSGW}}=$ new water contribution from shallow groundwater in the rift floor; $\delta^{18} \mathrm{O}_{\mathrm{HGW}}=$ pre-mixing mean isotopic composition of the highland groundwater.

Applying Eq. (1), a mixing ratio of $30 \%$ is found for the shallow groundwater contribution to the thermal system. The remaining proportion is deep circulating groundwater coming from the upper catchment as indirect recharge. The mixing proportion is mostly higher near fault zones, where it amounts to nearly $50 \%$; away from the fault zone the mixing ratio decreases. This highlights the control which faults have on the mixing rate. As the sampling points used for this calculation are closer to the escarpment than to the rift center, the mixing proportion is assumed to decrease towards the center of the rift floor where recharge is lower (Mechal et al. 2015).

Stable carbon isotope $\left(\delta^{13} \mathrm{C}\right)$

The stable carbon isotopic composition of DIC from the sampled groundwater ranges from -21.7 to $-1.7 \%$ (VPDB; Table 1). The highest $\delta^{13} \mathrm{C}_{\mathrm{DIC}}$ values belong to thermal groundwater in the rift floor $(-5.5$ to $-1.7 \%$ ), while the lowest $\delta^{13} \mathrm{C}_{\mathrm{DIC}}$ mainly refer to groundwater sampled in the escarpment and highland (-14.5 to $-21.7 \%$; Fig. 11 and Table 1). Such a wide $\delta^{13} \mathrm{C}_{\mathrm{DIC}}$ range could reflect multiple carbon sources and varying levels of geochemical evolution.

The ${ }^{13} \mathrm{C}$ isotopic composition of gaseous $\mathrm{CO}_{2}$ can be recalculated by using isotopic equilibrium fractionation according to the expression

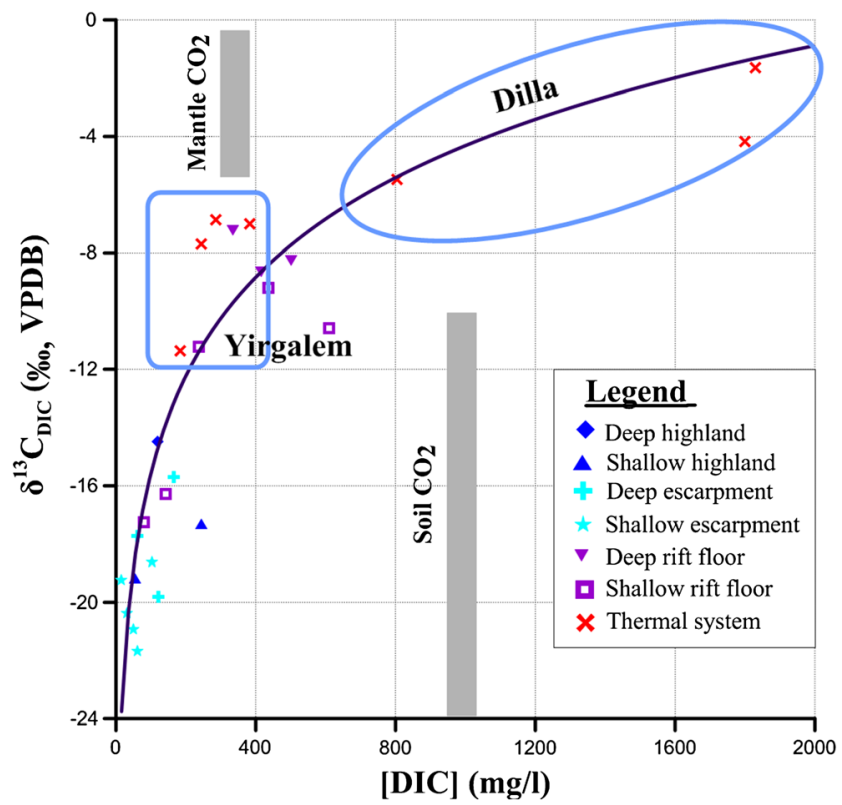

Fig. 11 Relationship of stable carbon isotopes $\left(\delta^{13} \mathrm{C}_{\text {DIC }}\right)$ with [DIC] of the water 
$\delta^{13} \mathrm{C}_{\mathrm{CO}_{2}}=\frac{\left(\delta^{13} \mathrm{C}_{\mathrm{CO}_{2}}+10^{3}\right)}{\alpha_{\mathrm{DIC}}}-10^{3}$

(e.g. Dietzel and Kirchhoff 2003), where

$$
\begin{aligned}
\alpha_{\text {DIC }} & =\left({ }^{13} \mathrm{C} /{ }^{12} \mathrm{C}\right)_{\text {DIC }} /\left({ }^{13} \mathrm{C} /{ }^{12} \mathrm{C}\right)_{\mathrm{CO} 2} \\
& =x_{\mathrm{f}} \cdot \alpha_{\mathrm{f}}+x_{\mathrm{b}} \cdot \alpha_{\mathrm{b}}+x_{\mathrm{c}} \cdot \alpha_{\mathrm{c}}
\end{aligned}
$$

The ${ }^{13} \mathrm{C} /{ }^{12} \mathrm{C}$ fractionation coefficient between DIC and gaseous $\mathrm{CO}_{2}$ is calculated from the individual ${ }^{13} \mathrm{C} /{ }^{12} \mathrm{C}$ fractionation coefficients $\alpha_{\mathrm{f}}, \alpha_{\mathrm{b}}$, and $\alpha_{\mathrm{c}}$ at isotope equilibrium (Vogel et al. 1970; Mook et al. 1974; Thode et al. 1965; respectively). The molar proportions $x_{\mathrm{f}}, x_{\mathrm{b}}$, and $x_{\mathrm{c}}$ are the molar fractions for $\mathrm{H}_{2} \mathrm{CO}_{3}{ }^{*}, \mathrm{HCO}_{3}{ }^{-}$, and $\mathrm{CO}_{3}{ }^{2-}$, respectively, obtained by hydrochemical modeling using the computer code PHREEQC (Parkhurst and Appelo 1999) with the PHREEQC database. The calculated ${ }^{13} \mathrm{C} /{ }^{12} \mathrm{C}$ composition of the $\mathrm{CO}_{2}$ gas for the dissolution of the volcanic rocks in an open system with respect to the gas phase is presented in Table 1. The upper catchment and thermal groundwater systems exhibit $\delta^{13} \mathrm{C}_{\mathrm{CO} 2}$ values from -16.6 to -4.8 and from -22.5 to $-17.4 \%$ o (VPDB), respectively.

The DIC in groundwater may be released from four main sources having different carbon isotope signatures: (1) biogenic processes (soil respiration) with $\delta^{13} \mathrm{C}$ values lower than $-23 \%$ (VPDB); (2) dissolved limestone (e.g. marine limestone $\delta^{13} \mathrm{C}$ close to $0 \%$, VPDB); (3) metamorphic processes with $\delta^{13} \mathrm{C}$ slightly above $0 \%$ (VPDB) and (4) mantle origin having values between -3 and $-8 \%$ (VPDB; Javoy et al. 1986; Vogel 1993; Mayo and Muller 1997; Marty and Zimmermann 1999; Cartigny et al. 2001; Carreira et al. 2010; Alemayehu et al. 2011).

The stable $\left(\delta^{18} \mathrm{O}\right.$ and $\left.\delta^{2} \mathrm{H}\right)$ isotopic composition of groundwater in the study area reveals local meteoric origin (Fig. 9a). As water infiltrates through the soil zone, DIC is gained by dissolution of carbon dioxide gas that exists in the soil as a result of biological activity. Both $\mathrm{C}_{3}$ plants (e.g. coffee, eucalyptus tree, mango) and $\mathrm{C}_{4}$ plants (e.g. grasses, maize, sorghum), which are assumed to be the main source of soil $\mathrm{CO}_{2}$, are widely available. The $\delta^{13} \mathrm{C}$ of soil $\mathrm{CO}_{2}$ in most $\mathrm{C}_{3}$ landscapes is generally about $-23 \%$, while that of soilhosting $\mathrm{C}_{4}$ plants is closer to about $-9 \%$ (Vogel 1993). The $\delta^{13} \mathrm{C}$ signature of soil $\mathrm{CO}_{2}$ in the study area is therefore assumed to be within $\mathrm{C}_{3}$ and $\mathrm{C}_{4}$ plant range ( $-23 \%$ o to $-9 \%$ ).

Hence, it is plausible to interpret that the $\delta^{13} \mathrm{C}_{\mathrm{DIC}}$ value of shallow groundwater all over the catchment show typical soil carbon source from $\mathrm{C}_{3}$ and $\mathrm{C}_{4}$ plants, explaining in part the wide range of $\delta^{13} \mathrm{C}_{\text {DIC }}$ values observed (Fig. 11). The calculated $\delta^{13} \mathrm{C}_{\mathrm{CO} 2}$ of the shallow groundwater also shows similar signature to soil carbon; however, the $\delta^{13} \mathrm{C}_{\text {DIC }}$ signature of the thermal groundwater in the rift floor cannot be explained only by soil $\mathrm{CO}_{2}$. The anomalous TDS and DIC measured in the highly enriched $\delta^{13} \mathrm{C}$ thermal groundwater cannot be only the result of the hydrochemical evolution as the groundwater flows from the highland to the rift floor. Beside the soil $\mathrm{CO}_{2}$, there should be additional $\mathrm{CO}_{2}$ triggering the silicate hydrolysis resulting in a high TDS and DIC signature of the thermal groundwater. The stratigraphic sequence of the region shows that the basement (metamorphic) rocks are capped by a very thin layer of residual sandstone; above this layer the volcanic rocks continue to the surface (Ebinger et al. 1993); therefore, sedimentary rocks (limestone) are missing and cannot be the source of $\mathrm{CO}_{2}$. Considering the location of the thermal groundwater in a volcanic setting especially in the highly faulted zone of the rift floor associated with plate boundaries, mantle $\mathrm{CO}_{2}$ ascending through deep-seated faults may be reasonably assumed as the additional $\mathrm{CO}_{2}$ source, which is also suggested by $\delta^{13} \mathrm{C}_{\mathrm{CO} 2}$ range of the thermal groundwater (Table 1).

Therefore, the analyzed $\delta^{13} \mathrm{C}_{\mathrm{DIC}}$ range can be interpreted by the origin of $\mathrm{CO}_{2}$ from mainly two sources: soil and mantle $\mathrm{CO}_{2}$. An additional source is also atmospheric $\mathrm{CO}_{2}$, although the amount should be very limited. Groundwater from the highland and upper escarpment which is characterized by low $\mathrm{pH}$ and DIC as well as depleted $\delta^{13} \mathrm{C}$ indicates a soil $\mathrm{CO}_{2}$ source causing less silicate weathering (Fig. 11). The exceptionally enriched $\delta^{13} \mathrm{C}$ value of DIC in thermal groundwater that displays the highest $\mathrm{pH}$ and DIC indicates the presence of mantle $\mathrm{CO}_{2}$ causing strong silicate weathering. Further evolved groundwater from the upland towards the lower escarpment and shallow rift floor area has intermediate $\mathrm{pH}$, DIC and $\delta^{13} \mathrm{C}$ signature. These can be explained as mixtures of the two end members: soil and mantle $\mathrm{CO}_{2}$.

The thermal groundwater in the rift floor displays strong variability in the groundwater composition, for instance wide ranges of TDS (225-2,320 mg/l) with parallel enrichment of $\delta^{13} \mathrm{C}_{\text {DIC }}$ signature. Thermal groundwater characterized by higher TDS values and enriched in $\delta^{13} \mathrm{C}_{\mathrm{DIC}}(\geq 5.5 \%$; Fig. 11; e.g. thermal springs close Dilla town) is related to strong waterrock interaction aided by mantle $\mathrm{CO}_{2}$ coming through the deep seated faults, whereas the lower TDS values and relatively depleted $\delta^{13} \mathrm{C}_{\mathrm{DIC}}$ signature (e.g. thermal springs close to the town of Yirgalem) are linked to the evolution of groundwater along the flow path from the highland towards the rift floor. This suggests that the influx of $\mathrm{CO}_{2}$ from a mantle source through fault systems locally is a relevant process controlling the rate of water-rock interaction in the rift floor.

\section{Conceptual hydrogeological model}

The conceptual model of the hydrogeological system of Gidabo River Basin is presented based on the evidence obtained from geomorphological, geological, hydraulic, hydrochemical and isotopic data (Fig. 12). This multi-proxy approach provided important information to achieve the 
Zone of minor recharge

$(25-100 \mathrm{~mm} /$ year) and almost no groundwater inflow from upland
Zone of moderate recharge (100-250 mm/year), major barrier for the E-W groundwater flow and discharge into the swamps, wet lands and thermal springs
Zone of high recharge $(250-400 \mathrm{~mm} /$ year $)$ and local discharge to springs and rivers

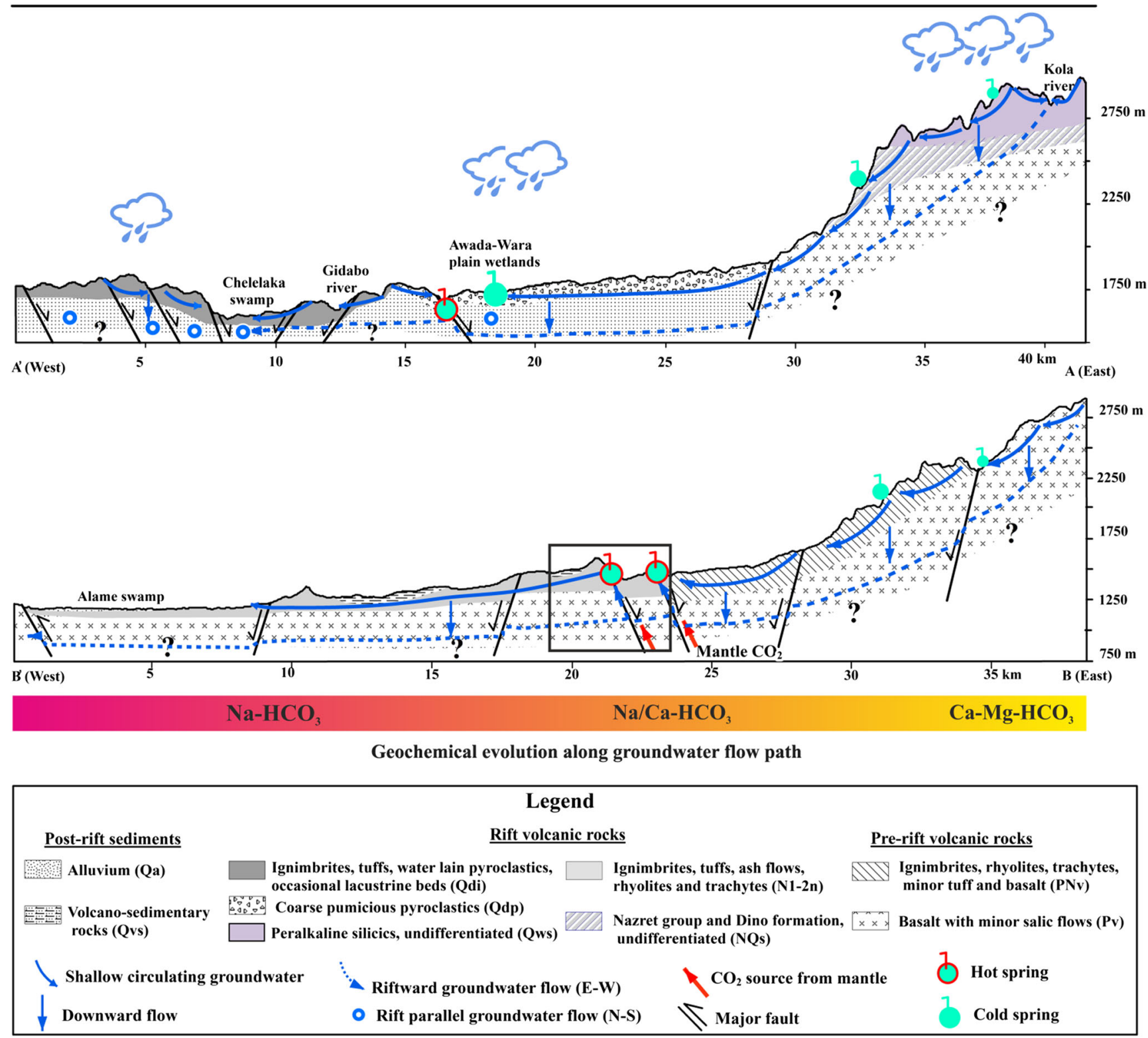

Fig. 12 A schematic cross section (E-W), showing the hydrogeological conceptual model of the Gidabo River Basin. The location of the cross-sections and their view direction are shown in Fig. 1. The area outlined by the square inset is displayed in Fig. 13

conceptual model of the groundwater circulation from the upland towards the main rift axis.

The geomorphologic setting of the area is characterized by the high mountain area to the east, the single prominent rift boundary fault escarpment and the floor of the rift valley in the west. The rift valley floor comprises a series of NNE-SSW trending horst and graben structures and right stepping faults running parallel to the NE-SW trending main rift axis. Recharge mainly takes place in the mountain and upper escarpment in the order of $300-400 \mathrm{~mm} /$ year and gradually drops towards the center of the rift floor $(25 \mathrm{~mm} /$ year $)$ due to increasing evapotranspiration and decreasing rainfall rate
(Mechal et al. 2015). Interlayered weathered and fractured basalts and ignimbrites are the major aquifers in the highland and escarpment, whereas the main aquifers in the rift floor are composed of a mixture of pyroclastic flows (ignimbrite and pumice) or alluvial and lacustrine deposits. Due to the absence of a conceivable extended confining layer and severe disruption of the multi-layer aquifers by various deep-seated faults, a good hydraulic connection is assumed to exist.

As the aquifer system in the area comprises unconfined aquifers overlying semi-confined aquifers, recharge occurs all over the basin. In the highland and escarpment, parts of the water recharged to the shallow aquifer system discharge to 
the nearby depressions along the rift boundary fault contributing to the baseflow of streams and springs, while the remaining water moves through the rocks to the deeper aquifers and joins the regional groundwater flow towards the rift floor (Fig. 12); therefore, shallow and localized groundwater flow paths are superimposed on deeper regional pathways. This is clearly seen by the progressive increase in spring discharge starting from the highland to the rift floor, suggesting that the rift boundary fault plays a major role in the occurrence of springs and the drainage of groundwater from the highland and escarpment into the rift floor aquifers. Likewise the water level map (Fig. 4) shows that groundwater flows regionally from the upland areas in the east towards the rift floor. The systematic trends of groundwater temperature, TDS, major ion concentrations and environmental isotopes $\left(\delta^{2} \mathrm{H}, \delta^{18} \mathrm{O}\right.$, and $\delta^{13} \mathrm{C}$ ) further support the existence of a hydraulic connection and groundwater movement from the highland and escarpment to the deep rift floor aquifers. The results of a highly simplified 2D groundwater model of Gidabo River Basin (Mechal et al. 2016) also suggest that the rift floor aquifers receive a significant contribution of groundwater flow from the highland and escarpment (mountain-block recharge).

However, groundwater movement within the rift floor is very elusive and highly influenced by geological structures. The change in aquifer configuration and topography due to faults has substantial impact on groundwater flow and is strongly dependent on the dip direction and scale of the normal faults. Normal faults dipping to the east likely act not only as (leaky) barriers to the horizontal flow but also as conduits parallel to the fault plane, thus favoring the existence of thermal springs, wetlands and swamps (Fig. 13), whereas westward dipping faults (e.g. the rift boundary fault) are assumed to facilitate the downward movement and transfer from the highland towards Lake Abaya (Fig. 12). For instance, the discharge of exceptionally mineralized hot water near the

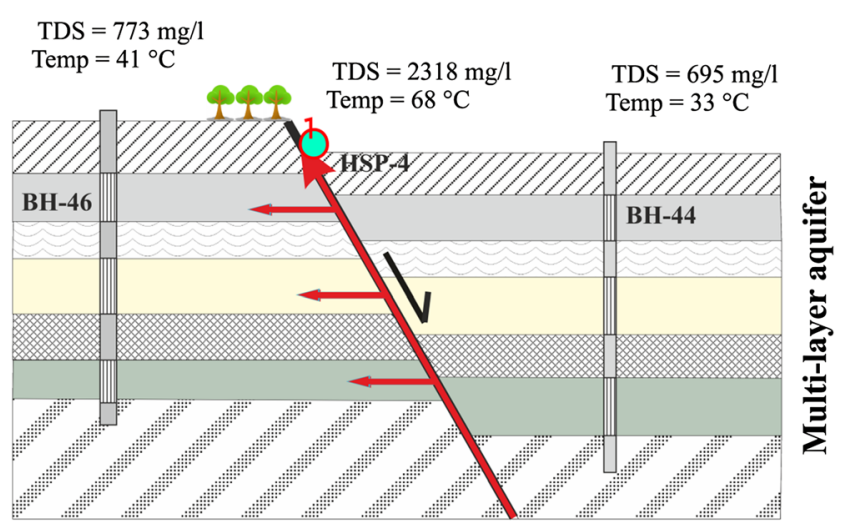

\section{Hydraulic gradient}

Fig. 13 An example of the hydrogeological behavior of faults (e.g. Odo mike fault zone close to the town of Dilla) acting as both semi-barriers and conduits. The red arrows show the assumed groundwater flow paths in the fault zone delineated by hydrochemical data. See Fig. 12 for the location of the fault in the cross section line B- $\mathrm{B}^{\prime}$ boiling point in the thermal springs, which are highly influenced by mantle $\mathrm{CO}_{2}$ coming through the fault system, is indicative of faults acting as hydraulic conduits connecting shallow and deep circulating groundwater; the faults simultaneously act as barriers to horizontal flow across the fault. The thermal springs are concentrated along the fault line; their lateral extent can be inferred from deep geothermal boreholes with similar hydrochemical and isotopic signatures crossing through the faults (Fig. 13), which is probably related to the presence of multi-layer aquifers in which the groundwater has different options to pass through the fault zones. This is consistent with the aforementioned hypothesis that the faults in the region generally act as complex conduit leaky barrier systems in which preferential or enhanced flow along the fault plane occurs, while flow across the fault is semi-impeded. Similar hydraulic and thermal effects of fault zones were reported, e.g. by Bense et al. (2008).

To characterize the general groundwater movement within the rift floor, the area is categorized as northern and southern rift floor. The northern part of the rift floor is characterized by the WFB system. The horst-graben structures are well developed by the combination of the above fault systems together with the prominent right-stepping faults rising above $2,000 \mathrm{~m}$ a.s.l. in the rift floor. The water level map (Fig. 4) indicates two major flow directions within the rift floor: across the rift $(\mathrm{E}-\mathrm{W})$ and parallel to the rift $(\mathrm{N}-\mathrm{S})$. The series of eastward dipping faults are a major barrier for the groundwater coming from the upper catchment and drain parallel to sub-parallel to the axis of the rift towards Lake Abaya following the elevation gradient. The fault-induced topography (horst-graben structures) creates low-lying zones of wetlands and swamps, representing the major sinks for groundwater flow in the northern area (Fig. 12). As a result, the overall westward moving groundwater is gradually diverted towards the rift parallel flow system. This conceptual model is also supported by the hydrochemical and isotope data: In the area west of the towns Hantete and Derara (see Fig. 1) both shallow (e.g. BH-176) and deep (e.g. BH-194) groundwater are enriched in $\delta^{18} \mathrm{O}$ and $\delta^{2} \mathrm{H}$ and are only slightly mineralized (TDS $<250 \mathrm{mg} /$ l), suggesting a dominance of the local recharge over the deep regional flow component, which is consistent with the aforementioned diversion of the regional groundwater flow from E-W to N-S. In contrast, in the southern and central part of the study area, the general groundwater flow is straight $\mathrm{E}-\mathrm{W}$ towards Lake Abaya. This needs further investigation but might be attributed to the generally lower abundance, small throw and lateral pinching of faults in this area.

\section{Conclusion}

Hydrochemical and isotope data together with well head and spring discharge observations enabled characterization of the 
regional groundwater flow pattern and how it is influenced by the tectonic setting of the rift in the Gidabo River Basin. The techniques employed are mutually supportive and the extracted information was used to develop a conceptual hydrogeological model characterizing the flow paths to the main rift axis, advancing the general understanding of the complex hydrogeological system of the Ethiopian Rift.

Both the observed groundwater levels and the hydrochemical and isotopic composition of the groundwater indicate groundwater flow from the major recharge area in the highland and escarpment into deep rift floor aquifers. Thus, a deep regional flow system can be distinguished from the shallow local aquifers. As a result of the deep groundwater circulation and the high geothermal gradients, thermal groundwater and hot springs are found in the rift floor.

Groundwater gradually evolves from slightly mineralized $\mathrm{Ca}-\mathrm{Mg}-\mathrm{HCO}_{3}$ type in the highland to highly mineralized $\mathrm{Na}-$ $\mathrm{HCO}_{3}{ }^{-}$type in the rift floor. The hydrochemical evolution of groundwater is largely linked to silicate hydrolysis by the uptake of gaseous $\mathrm{CO}_{2}$ gained from soil; however, locally in the rift floor, deep circulating thermal groundwater is additionally loaded with mantle $\mathrm{CO}_{2}$ coming through deep-seated faults. The influx of mantle $\mathrm{CO}_{2}$ enhances silicate hydrolysis and thus leads to a locally anomalous composition of the thermal waters with high TDS and high fluoride concentrations. Yet, unlike the central and northern MER, suffering water quality problems due to high salinity and high fluoride content, the majority of groundwater in the Gidabo River Basin displays rather diluted solutions.

The $\delta^{18} \mathrm{O}$ and $\delta^{2} \mathrm{H}$ data indicate meteoric origin and little modification by evaporation and subsurface processes such as rock-water interactions and exchange with $\mathrm{CO}_{2}$ emerging from the mantle through fault systems. The spatial variability of $\delta^{18} \mathrm{O}$ and $\delta^{2} \mathrm{H}$ is controlled by the elevation of the recharge area and the mixing of local recharge and deep regional groundwater flow. The main recharge areas of the deep aquifers are located in the highland, probably around 2,600 $\mathrm{m}$ a.s.l. The rift floor aquifers are recharged from local precipitation and regional groundwater flow from the escarpment and highland aquifers (mountain-block recharge). A two-component mixing analysis suggests that the shallow groundwater contributes on average around $30 \%$ to the thermal groundwater system in the rift floor. Near fault zones, the contribution of the shallow groundwater to the thermal groundwater is found to be higher.

Groundwater movement within the rift floor is complex and highly constrained by geological structures. Normal faults dipping to the west appear to facilitate movement of groundwater into deeper aquifers and towards the rift floor, whereas those dipping to the east tend to act as leaky barriers perpendicular to the fault but enable preferential flow parallel to the fault plane. As a result, the series of horst graben structures together with the prominent right-stepping faults are major barriers and sinks for the local groundwater circulation in the northern rift floor.
Groundwater coming E-W from the upland is diverted and drained parallel to sub-parallel $(\mathrm{N}-\mathrm{S})$ to the axis of the rift towards Lake Abaya. In contrast, the general groundwater flow in the southern and central part of the rift floor is straight E-W towards Lake Abaya. Further local investigations will be needed to obtain a more detailed understanding of the hydraulic functioning of the individual fault zones and their influence on the groundwater flow pattern within the rift.

Acknowledgements Open access funding provided by University of Graz. The Austrian Partnership Programme in Higher Education and Research for Development (APPEAR) is acknowledged for a $\mathrm{PhD}$ research grant to the first author. Sidama, Gedeo and Borena zone water resources development offices are warmly thanked for their guidance during the field work and delivering well completion reports. Hydrochemical and isotope analyses were conducted at NAWI Graz Central Lab for Water, Minerals and Rocks, Johanneum Research, Institute of Water, Energy and Sustainability and Addis Ababa University, school of Earth Science. The authors acknowledge A. Baldermann, J. Jernej, and A. Wolf for support with liquid analyses. The authors would like to thank T. Wagner and J. Woitischek for the fruitful discussions during the work and Isaac John Kell Duivestein for English language editing. Comments by Victor Bense and two anonymous reviewers helped improve the manuscript.

Open Access This article is distributed under the terms of the Creative Commons Attribution 4.0 International License (http:// creativecommons.org/licenses/by/4.0/), which permits unrestricted use, distribution, and reproduction in any medium, provided you give appropriate credit to the original author(s) and the source, provide a link to the Creative Commons license, and indicate if changes were made.

\section{References}

Acocella V, Korme T, Salvini F (2003) Formation of normal faults along the axial zone of the Ethiopian Rift. J Struct Geol 25:503-513

AG Consult (2004) Hydrogeological mapping of Yirgalem and Kilissa sub sheet. SNNPR Water Resources Development Bureau, Awassa, Ethiopia, $85 \mathrm{pp}$

Alemayehu T, Leis A, Eisenhauer A, Dietzel M (2011) Multi-proxy approach $\left({ }^{2} \mathrm{H} / \mathrm{H},{ }^{18} \mathrm{O} / 16 \mathrm{O},{ }^{13} \mathrm{C} /{ }^{12} \mathrm{C}\right.$ and $\left.{ }^{87} \mathrm{Sr} /{ }^{86} \mathrm{Sr}\right)$ for evolution of carbonate-rich groundwater in a basalt dominated aquifer, northern Ethiopia. Geochemistry 71(2):177-187. doi:10.1016/j. chemer.2011.02.007

Anderson E, Bakker M (2008) Groundwater flow through anisotropic fault zones in multi-aquifer systems. Water Resour Res 44: W11433. doi:10.1029/2008WR006925

Ayenew T (1998) The Hydrogeological system of the Lake District basin, central main Ethiopian Rift. Publ. no. 64, PhD Thesis, ITC, Enschede, The Netherlands

Ayenew T, Kebede S, Abiye TA (2008) Environmental isotopes and hydrochemical study as applied to surface water and groundwater interaction in Awash basin. Hydrol Process 22:1548-1563. doi:10.1002/hyp.6716

Ayenew T, Fikre S, Wisotzky F, Demlie M, Wohnlich S (2009) Hierarchical cluster analysis of hydrochemical data as a tool for assessing the evolution and dynamics of groundwater across the Ethiopian Rift. Int J Phys Sci 4(2):76-90 
Bense VF, Person M (2006) Faults as conduit-barrier systems to fluid flow in siliciclastic sedimentary aquifers. Water Resour Res 42: W0542. doi:10.1029/2005WR004480

Bense VF, Van Balen RT, DeVries JJ (2003) The impact of faults on the hydrogeological conditions in the Roer Valley Rift System: an overview. Neth J Geosci 82:41-53

Bense VF, Person M, Chaudhary K, You Y, Cremer N, Simon S (2008) Thermal anomalies as indicator of preferential flow along faults in an unconsolidated sedimentary aquifer system. Geophys Res Lett 35:L24406. doi:10.1029/2008GL036017

Bense VF, Gleesonb T, Loveless SE, Bour O, Scibek J (2013) Fault zone hydrogeology. Earth-Sci Rev 127:171-192. doi:10.1016/j. earscirev.2013.09.008

Bethke CM, Johnson TM (2008) Groundwater age and groundwater age dating. Annu Rev Earth Planet Sci 36:121-152. doi:10.1146/annurev. earth.36.031207.124210

Boccaletti M, Bonini M, Mazzuoli R, Abebe B, Piccardi L, Tortorici L (1998) Quaternary oblique extensional tectonics in the Ethiopian Rift (Horn of Africa). Tectonophysics 287:97-116. doi:10.1016/S00401951(98)80063-2

Brassington R (2007) Field hydrogeology, 3rd edn. Wiley, Chichester, UK

Bretzler A, Osenbrück K, Gloaguen R, Ruprecht J, Kebede S, Susanne Stadler S (2011) Groundwater origin and flow dynamics in active rift systems: a multi-isotope approach in the Main Ethiopian Rift. J Hydrol 402:274-289. doi:10.1016/j.jhydrol.2011.03.022

Carreira PM, Marques JM, Carvalho MR, Capasso G, Grassa F (2010) Mantle-derived carbon in Hercynian granites: stable isotopes signatures and $\mathrm{C} / \mathrm{He}$ associations in the thermomineral waters, $\mathrm{N}$ Portugal. J Volcanol Geoth Res 189(1-2):49-56. doi:10.1016/j. jvolgeores.2009.10.008

Cartigny P, Jendrzejewski N, Pineau F, Petit E, Javoy M (2001) Volatiles $(\mathrm{C}, \mathrm{N}, \mathrm{Ar})$ variability in MORB and the respective roles of the mantle source heterogeneity and degassing: the case of the South West Indian Ridge. Earth Planet Sci Lett 194:241-257

Chernet T (1982) Hydrogeology of the lakes region, Ethiopia (Lakes Ziway, Langano, Abitata, Shalla and Awassa). In: The provisional military government of socialist Ethiopia-ministry of mines and energy. Ethiopian Institute of Geological Surveys, Addis Ababa, Ethiopia, $97 \mathrm{pp}$

Chernet T, Hart WK, AronsonJL WRC (1998) New age constraints on the timing of volcanism and tectonism in the northern Main Ethiopian Rift-southern Afar transition zone (Ethiopia). J Volcanol Geotherm Res 80:267-280

Chernet T, Travi Y, Valles V (2001) Mechanism of degradation of the quality of natural water in the lakes region of the Ethiopian Rift Valley. Water Res 35:2819-2832

Chowdhury AH, Uliana M, Wade S (2008) Groundwater recharge and flow characterization using multiple isotopes. Ground Water 46(3): 426-436. doi:10.1111/j.1745-6584.2008.00443.x

Clark I, Fritz P (1997) Environmental isotopes in hydrogeology. Lewis, Boca Raton, FL

Craig H (1961) Standards for reporting concentration of deuterium and oxygen-18 in natural waters. Science 133:1833-1834

Craig H (1963) The isotopic geochemistry of water and carbon in geothermal areas. In: Nuclear Geology in Geothermal Areas, Spoleto. Laboratorio di Geologia Nucleare, Pisa, Italy, pp 17-53

D'Amore F, Panichi C (1987) Geochemistry in geothermal exploration, chap 5. In: Economides MJ, Ungemach PO (eds) Applied geothermics. Wiley, New York, pp 69-88

Dansgaard W (1961) The isotopic composition of natural waters. Medd Groenl 165:1-120

Darling WG (1996) The geochemistry of fluid processes in the eastern branch of the East African rift system. PhD Thesis, Open University, Milton Keynes, UK
Darling WG, Gizaw B (2002) Rainfall-groundwater isotopic relationships in eastern Africa: the Addis Ababa anomaly. In: Study of environmental change using isotopic techniques. Proceedings of an international conference held in Vienna, Austria, 23-27 April 2001, pp 489-490

Debisso B (2009) Groundwater resource assessment in the Gidabo river catchment, southern main Ethiopian Rift province, YirgalemWonago. MSc Thesis, Addis Ababa University, Addis Ababa, Ethiopia, $134 \mathrm{pp}$

Dietzel M, Kirchhoff T (2003) Stable isotope ratios and the evolution of acidulous solutions. Aquat Geochem 8(4):229-254

Dogramaci S, Firmani G, Hedley P, Skrzypek G, Grierson PF (2015) Evaluating recharge to an ephemeral dryland stream using a hydraulic model and water, chloride and isotope mass balance. J Hydrol 521:520-532

Ebinger CJ, Yemane T, WoldeGabriel G, Aronson JL, Walter RC (1993) Late Eocene-Recent volcanism and faulting in the southern Main Ethiopian Rift. J Geol Soc Lond 150:99-108

Fontes JC (1980) Environmental isotopes in ground water hydrology. In: Fritz P, Fontes JC (eds) Handbook of environmental isotope geochemistry, the terrestrial environment, vol 1. Elsevier, Amsterdam, pp 75-134

Furi W, Razack M, Haile T, Abiye TA, Legesse D (2011) The hydrogeology of Adama-Wonji basin and assessment of groundwater level changes in Wonji wetland, Main Ethiopian Rift: results from 2D tomography and electrical sounding method. Environ Earth Sci 62(6):1323-1335. doi:10.1007/s12665-010-0619-y

Gat JR (1971) Comments on the stable isotope method in regional groundwater investigations. Water Resour Res 7:980-993. doi:10.1029/WR007i004p00980

Gizaw B (1996) The origin of high bicarbonate and fluoride concentrations in waters of the Main Ethiopian Rift Valley, East African Rift system. J Afr Earth Sci 2:391-402

GSE (2012) Geological, geochemical and gravity survey of the central and south western Ethiopia. Dilla map sheet, Geological Survey of Ethiopia (GSE), Addis Ababa, Ethiopia

Halcrow (2008) Rift Valley Lakes integrated natural resources development master plan. Ethiopian Valleys Development Studies Authorities, Ministry of Water Resources, Addis Ababa, Ethiopia

Haneberg WC (1995) Steady state groundwater flow across idealized faults. Water Resour Res 31(7):1815-1820. doi:10.1029/95 WR01178

Herczeg AL, Dogramaci SS, Leaney FWJ (2001) Origin of dissolved salts in a large, semi-arid groundwater system: Murray Basin, Australia. Mar Freshw Res 52(1):41-52. doi:10.1071/MF00040

Javoy M, Pineau F, Delorme H (1986) Carbon and nitrogen isotopes in the mantle. Chem Geol 57:41-62. doi:10.1016/0009-2541 (86)90093-8

Joseph A, Frangi P, Aranyossy JF (1992) Isotopic composition of meteoric water and groundwater in the Sahelo-Sudanese zone. J Geophys Res 97:7543-7551. doi:10.1029/92JD00288

Kebede S (2004) Approches isotopique et geochimique pour l'etude des eaux souterraines et des lacs: exemples du haut bassin du Nil Bleu et $\mathrm{du}$ rift Ethiopien [Environmental isotopes and geochemistry in groundwater and lake hydrology: cases from the Blue Nile basin, main Ethiopian rift and Afar, Ethiopia]. PhD Thesis, University of Avignon, France

Kebede S (2013) Groundwater in Ethiopia: features, numbers and opportunities. Springer, Heidelberg, Germany

Kebede S, Travi Y (2011) Origin of the $\delta^{18} \mathrm{O}$ and $\delta^{2} \mathrm{H}$ composition of meteoric waters in Ethiopia. Quat Int 257:4-12. doi:10.1016/j. quaint.2011.09.032

Kebede S, Travi Y, Asrat A, Alemayehu T, Ayenew T, Tessema Z (2008) Groundwater origin and flow along selected transects in Ethiopian rift volcanic aquifers. Hydrogeol J 16(1):55-73. doi:10.1007/s10040-007-0210-0 
Kebede S, Travi Y, Stadler S (2010) Groundwaters of the Central Ethiopian Rift: diagnostic trends in trace elements, ${ }^{18} \mathrm{O}$ and major elements. Environ Earth Sci 61:1641-1655. doi:10.1007/s12665010-0479-5

Korme T, Acocella V, Abebe B (2004) The role of pre-existing structures in the origin, propagation and architecture of faults in the Main Ethiopian Rift. Gondwana Res 7:467-479. doi:10.1016/S1342-937 $\mathrm{X}(05) 70798-\mathrm{X}$

Kurz T, Gloaguen R, Ebinger C, Casey M, Abebe B (2007) Deformation distribution and type in the Main Ethiopian Rift (MER): a remote sensing study. J African Earth Sci 48(2-3):100-114. doi:10.1016/j. jafrearsci.2006.10.008

Leray S, de Dreuzy JR, Bour O, Labasque T, Aquilina L (2012) Contribution of age data to the characterization of complex aquifers. J Hydrol 464-465:54-68. doi:10.1016/j.jhydrol.2012.06.052

Levin NE, Zipser EJ, Cerling TE (2009) Isotopic composition of waters from Ethiopia and Kenya: insights into moisture sources for eastern Africa. J Geophys Res 114:D23306. doi:10.1029/2009JD012166

Marty B, Zimmermann L (1999) Volatiles (He, C, N, Ar) in mid-ocean ridge basalts: assessment of shallow-level fractionation and characterisation of source composition. Geochim Cosmochim Acta 63: 3619-3633. doi:10.1016/S0016-7037(99)00169-6

Masiyandima M, Giordano M (2007) Sub-Saharan Africa: opportunistic exploitation. In: Giordana M, Villhoth KG (eds) The agricultural groundwater revolution: opportunities and threats to development. CAB, Wallingford, UK, pp 79-99

Mayo AL, Muller AB (1997) Low temperature diagenetic-metamorphic and magmatic contributions of external $\mathrm{CO} 2$ gas to a shallow ground water system. J Hydrol 194:286-304. doi:10.1016/S00221694(96)03215-5

Mazor E (2004) Applied chemical and isotopic groundwater hydrology. Open University, Buckingham, UK

Mechal A (2007) Groundwater resource assessment in the Buna river catchment: Dilla, southern Ethiopia. MSc Thesis, Addis Ababa University, Addis Ababa Ethiopia, $118 \mathrm{pp}$

Mechal A, Wagner T, Birk S (2015) Recharge variability and sensitivity to climate: the example of Gidabo River Basin, southern Main Ethiopian Rift. J Hydrol Regul Stud 4:644-660. doi:10.1016/j. ejrh.2015.09.001

Mechal A, Birk S,Winkler G, Wagner T, Mogessie A (2016) Characterizing regional groundwater flow in the Ethiopian Rift: a multi-model approach applied to Gidabo River Basin. Aust J Earth Sci 109(1):68-83. doi: 10.17738/ajes.2016.0005

Mohr P (1962) The Ethiopian Rift system. Geophys Obs Addis Ababa Bull 5:33-62

Mook WG, Bommerson JC, Stavermann WH (1974) Carbon isotope fractionation between dissolved bicarbonate and gaseous carbon dioxide. Earth Planet Sci Lett 22:169-176. doi:10.1016/0012-821 $\mathrm{X}(74) 90078-8$

Mussie M (2007) Groundwater circulation and hydrochemistry of the corridor (upper Gidabo river and lakeAwassa catchments), Sidama zone, SNNPR. MSc Thesis, Addis Ababa University, Addis Ababa, Ethiopia, $179 \mathrm{pp}$

Negussei Y (1990) Groundwater resource study of the Gidabo basin, Southern Rift Valley of Ethiopia, Reconnaissance study, MSc Thesis, ITC, Enschede, The Netherlands

Parkhurst DL, Appelo CAJ (1999) User's guide to PHREEQC (version 2): a computer program for speciation, batch-reaction, onedimensional transport and inverse geochemical calculations. US Geol Surv Water Resour Invest Rep 99-4259

Rango T, Bianchini G, Beccaluva L, Ayenew T, Colombani N (2009) Hydrogeochemical study in the Main Ethiopian Rift: new insights to the source and enrichment mechanism of fluoride. Environ Geol 58:109-118. doi:10.1007/s00254-008-1498-3
Raunet M (1977) Gidabo basin Morpho-Pedological survey. MSc Thesis, IRAT, Paris

Reimann C, Bjorvatn K, Frengstad B, Melaku Z, TekleHaimanot R, Siewers U (2003) Drinking water quality in the Ethiopian section of the East African Rift Valley, part I: data and health aspects. Sci Total Environ 31:65-80. doi:10.1016/S0048-9697(03)00137-2

Rose TP, Davisson ML, Criss RE (1996) Isotope hydrology of voluminous cold springs in fractured rock from an active volcanic region, northeastern California. J Hydrol 179:207-236. doi:10.1016/00221694(95)02832-3

Rozanski K, Araguas-Araguas L, Gonfiantini R (1996) Isotope patterns of precipitation in the East African region. In: Johnson TC, Odada E (eds) The climatology, palaeoclimatoloy, paleoecology of the East African lakes. Gordon and Breach, Toronto, pp 79-93

Salameh E, Rimawi O (1984) Isotopic analyses and hydrochemistry of the thermal springs along the eastern side of the Jordan Dead SeaWadiAraba Rift Valley. J Hydrol 73:129-145. doi:10.1016/00221694(84)90036-2

Schofield S, Jankowski J (2004) Hydrochemistry and isotopic composition of $\mathrm{Na}-\mathrm{HCO}_{3}$ rich groundwaters from the Ballimore region, central New South Wales, Australia. Chem Geol 211:111-134. doi:10.1016/j.chemgeo.2004.06.026

Sonntag E, Klitzsch E, Lohnert EP, El-Shazly EM, Munnich KO, Junghans C, Thorweihe U, Weistroffer K, Swailem FM (1979) Palaeoclimatic Information from Deuterium and Oxygen-18 in Carbon-14 Dated North Saharian Groundwaters. Isotope Hydrology 1978, vol 2. International Atomic Energy Agency, Vienna

Spötl C (2005) A robust and fast method of sampling and analysis of $\delta^{13} \mathrm{C}$ of dissolved inorganic carbon in ground waters. Isot Environ Healt Stud 41(3):217-221. doi:10.1080/10256010500230023

Tekle-Haimanot R, Melaku Z, Kloos H, Reimann C, Fantaye W, Zerihun L, Bjorvatn K (2006) The geographic distribution of fluoride in surface and groundwater in Ethiopia with an emphasis on the Rift Valley. Sci Total Environ 367:182-190. doi:10.1016/j. scitotenv.2005.11.003

Thode HG, Shima M, Rees CE, Krishnamurty KV (1965) Carbon-13 isotope effects in systems containing carbon dioxide, bicarbonate, carbonate and metal ions. Can J Chem 43:582-595

UNDP (1973) Geology, geochemistry and hydrology of hot springs of the East African Rift system within Ethiopia. UNDP report DD/SF/ON11, UNDP, New York, 300 pp

Vogel JC (1993) Variability of carbon isotope fractionation during photosynthesis. In: Ehleringer JR, Hall AE, Farquhar GD (eds) Stable isotopes and plant carbon-water relations. Academic, San Diego, pp $29-46$

Vogel JC, Grootes PM, Mook WG (1970) Isotopic fractionation between gaseous and dissolved carbon dioxide. Z Phys 230:225-238

WHO (2011) Guidelines for drinking-water quality, 4th edn. World Health Organization, Geneva

WoldeGabriel G, Aronson JL, Walter RC (1990) Geology geochronology and rift basin development in the central sector of the Main Ethiopian Rift. Geol Soc Am Bull 102:439-458. doi:10.1130/0016-7606(1990)102<0439:GGARBD>2.3.CO;2

WoldeGabriel G, Heiken G, White TD, Asfaw B, Hart WK, Renne PR (2000) Volcanism, tectonism, sedimentation, and the paleoanthropological record in the Ethiopian Rift System. In: McCoy FW, Heiken $\mathrm{G}$ (eds) Volcanic hazards and disasters in human antiquity. Geol Soc Am Spec Pap 345:83-99

Yasin K (2002) Hydrogeology of upper Gidabo River catchment, southern Ethiopia. MSc Thesis, Addis Ababa University, Addis Ababa, Ethiopia 